ks. Bartosz Wronikowski, Alegoryczna interpretacja świątyni w pierwszej księdze „Rationale divinorum officiorum” Wilhelma Duranda, w: Przestrzeń liturgiczna, red. Adelajda Sielepin CHR, Jarosław Superson SAC, Kraków 2019, s. 125-164.

DOI: http://dx.doi.org/10.15633/9788374387828.07

ks. Bartosz Wronikowski

Centro Aletti, Rzym

\title{
Alegoryczna interpretacja świątyni w pierwszej księdze Rationale divinorum officiorum Wilhelma Duranda
}

Osoba Wilhelma Duranda jest w Polsce praktycznie nieznana. Jego nazwisko pojawia się zasadniczo tylko tam, gdzie wymieniania się średniowiecznych propagatorów metody alegorycznej. Na jego osobę można trafić w opracowaniach, które wymieniają twórców różnych ksiąg liturgicznych, np. jako autora pontyfikału - Pontificalis ordinis liber, jednak szersza jego działalność i twórczość pozostają w środowisku polskim bliżej nieznane. Głównym powodem takiego stanu rzeczy jest niewątpliwie brak przekładu na język polski jego dzieł. Dotarcie do tekstów w języku oryginalnym (łacińskim) czy przekładów na inne języki jest również praktycznie niemożliwe, gdyż bardzo trudno jest je znaleźć w bibliotekach naszego kraju. Chcąc się zapoznać z osobą i działalnością Duranda, trzeba sięgnąć przede wszystkim do publikacji włosko- i francuskojęzycznych, czyli pochodzących z regionów, gdzie autor żył i tworzył.

Obecny stan wiedzy o Durandzie i jego Rationale divinorum officiorum zawdzięczamy przede wszystkim pracy ojca Clarence'a Menarda. Przy pisaniu swojego doktoratu, obronionego w 1967 roku na Papieskim Uniwersytecie Gregoriańskim w Rzymie, podjął się kwerendy w wielu europejskich bibliotekach w celu odszukania rękopisów tego dzieła ${ }^{\mathrm{I}}$. Pozwoliło mu to uporządkować rękopisy, podzielić je na cztery rodziny i ustalić datację dzieła na lata I286-I29I. Bazując na doświadczeniu ojca Menarda, trzeba

\footnotetext{
Por. A. Davril, Préambule, w: Gvillelmi Dvranti Rationale divinorvm officiorvm I-IV, edit. A. Davril et T. M. Thibodeau, Tvrnholti I995, s. VII (Corpvs Christianorvm. Continuatio Mediaeualis, I40).
} 
podkreślić również wkład dwóch ekip badaczy. Do pierwszej należą: Dom Anselme Davril, mnich z Saint-Benoît-sur-Loire, dr Timothy Thibodeau i o. Bertrand Gyuot OP, którzy opracowali wydanie krytyczne Rationale divinorum officiorum wydane jako I40 tom Corpvs Christianorvm - Continuatio Mediaevalis. Natomiast do drugiej grupy można zaliczyć: Stefana della Torre, Massima Marinellego i Manlia Sodiego, którzy wydali w wersji dwujęzycznej (łacińsko-włoskiej) pierwszą i trzecią księgę Rationale divinorum officiorum, jako II tom serii Monumenta Studia Instrumenta Liturgica. Właśnie ta publikacja stanowiła podstawowe źródło analizy przedstawionej w niniejszym opracowaniu.

Celem artykułu jest przybliżenie alegorycznej interpretacji świątyni, opisanej przez Duranda w pierwszej księdze omawianego dzieła. Warto także zapoznać polskiego czytelnika z osobą tego wielkiego liturgisty i prawnika doby rozkwitu średniowiecza.

\section{Życiorys}

Wilhelm Durand (łac. Durandi, wł. Guillelmi Duranti, fr. Guillaume Durand) urodził się w Prowansji, w Puimisson, w diecezji Béziers, prawdopodobnie około I230 roku. Historia nazwała go Starszym lub Speculatorem, dla odróżnienia go od jego bratanka, Guillauma Duranda Młodszego. Zarówno jeden, jak i drugi zostali biskupami Mende pod koniec swojego życia².

Wilhelm Durand był przede wszystkim specjalistą prawa kanonicznego. Rozpoczął studia na uniwersytecie w Bolonii u Bernardusa z Parmy33. W Bolonii uzyskał tytuł doktora prawa kanonicznego (doctorum decretorum). Nauczał w Modenie, gdzie zyskał ogromne uznanie ${ }^{4}$.

Opatrzność Boża związała Duranda z posługą wobec następców św. Piotra. W I263 roku, na polecenie papieża Klemensa IV (I265-I268), został członkiem Kurii Rzymskiej, otrzymał tytuł kanonika Beauvais i Chartres ${ }^{5}$. Uczestniczył w wyjątkowym i historycznym konklawe w Witerbo, w I27I roku, w którym

\footnotetext{
2 Por. A. Davril, Préambule, dz. cyt., s. VII.

3 Por. S. della Torre, Per una lettura del ,Rationale” di Guglielmo Durando, w: G. Duranti, Rationale divinorum officiorum, direct. S. della Torre, M. Marinelli, Città del Vaticano 200I, s. XI (Monumenta Studia Instrumenta Liturgica, II).

4 Por. A. Davril, Préambule, dz. cyt., s. VII.

5 Por. A. Davril, Préambule, dz. cyt., s. VII.
} 
po raz pierwszy zamknięto kardynałów pod kluczem ${ }^{6}$. Od tego zamknięcia kardynałów i trzymania ich „pod kluczem” zrodziła się zresztą funkcjonująca do dziś nazwa „konklawe”.

W wyniku tego jednego z najdłuższych konklawe został wybrany papieżem Grzegorz X (I27I-I276). Tenże papież mianował Duranda swoim sekretarzem, dzięki czemu mógł on być obecny na II ekumenicznym soborze w Lyonie w I274 roku, na którym przeprowadzono reformę Kościoła, m.in. ustalono nowe normy elekcji biskupa Rzymu ${ }^{8}$, co było skutkiem doświadczeń towarzyszących wyborowi Grzegorza X. Durand zredagował, przynajmniej częściowo, dekrety tego soboru. $\mathrm{Z}$ tego doświadczenia pozostawił także sprawozdanie Komentarz do konstytucji soboru w Lyonie (Commentarius $w$ concilium sacrosanctum Lugdunense) ${ }^{9}$.

W tym rzymskim okresie Wilhelm Durand tworzył swoje największe kanoniczne dzieło Speculum iudiciale (albo iuris), dzięki któremu nadano mu przydomek Speculator. Celem dzieła jest stworzenie praktycznego przewodnika dla „wszystkich tych, którzy zajmują się procesami sądowymi”. Odniosło ono olbrzymi sukces, czego dowodzą liczne rękopisy przetrwałe aż do naszych czasów. Do swojego Speculum Wilhelm opracował także Repertorium (Breviarium), w którym pragnął w prowadzić porządek w zawiłości i nieścisłości prawa kanonicznego ${ }^{\mathrm{T}}$.

Funkcję zarządcy Patrimonium Sancti Petri pełnił przez kilka pontyfikatów. $\mathrm{Z}$ tej racji, w imieniu papieża Mikołaja III (I277-I280), w roku I278 przyjmował hołd od Romanii, która właśnie została włączona do Patrimonium Sancti Petri. Od tegoż papieża dostał nominację na dziekana Chartres, jednak papież

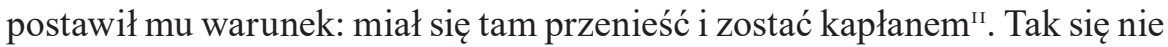
stało. Pozostając cały czas na usługach Stolicy Apostolskiej, Wilhelm Durand rozpoczął swoją karierę administracyjną, a nawet wojskową jako rector et capitaneus generalis. Papież Marcin IV (I28I-I285) mianował go W I28I roku wikarym, a w I283 tymczasowym gubernatorem Romanii i Toskanii (miasta

6 Por. A. Davril, Préambule, dz. cyt., s. VII; por. S. della Torre, Per una lettura..., dz. cyt., s. XI.

7 Cum clave z łac. clavis, is - klucz, a więc cum clave - pod kluczem. Por. Clavis, is, w: A. Jougan, Stownik kościelny łacińsko-polski, Poznań-Warszawa-Lublin I9583, s. II4.

8 Por. B. Kumor, Historia Kościoła, t. 3: Złoty kores średniowiecza chrześcijańskiego, Lublin 200I, s. I53.

9 Por. S. della Torre, Per una lettura ..., dz. cyt., s. XI.

Io Por. A. Davril, Préambule, dz. cyt., s. VII.

II Por. S. della Torre, Per una lettura ..., dz. cyt., s. XI. 
Ankona, Bolonia, Urbino). Rejon był ogarnięty wojną domową, a Durandowi udało się nawet uspokoić ten bunt, wywołany przez Guida di Montefeltro ${ }^{\mathrm{I} 2}$.

Kolejny papież Honoriusz IV (I285-I287) docenił te dokonania i pozostawił Duranda przy sobie, pomimo iż z Francji doszły wieści o jego szansach wyboru na biskupa Mende (w prowincji Narbonne - Masyw Centralny). Stanowisko biskupa w Mende nie było obsadzone od 278 roku. Durandowi brakowało jednak do objęcia tego stanowiska potrzebnych tytułów i święceń. Pomimo tych braków kapituła katedry w Mende mianowała go biskupem. W lecie I286 roku we Włoszech uzyskał konsekrację biskupią. Mimo że na swoje dotychczasowe stanowisko miał już następcę, nadal pozostawał na miejscu w Bolonii. Rządy w diecezji pozostawił na kilka lat bratankowi, Wilhelmowi Młodszemu. Ingres do katedry w Mende miał miejsce dopiero I4 lipca I29I roku. Sam Wilhelm Durand rezydował w swojej diecezji tylko przez cztery lata, od I29I do I295 roku ${ }^{13}$.

W I295 roku został wezwany przez papieża Bonifacego VIII (I294-I303) na arcybiskupstwo do Rawenny. Mimo że odmówił papieżowi przyjęcia arcybiskupstwa, nie popadł w niełaskę. Dowodzi to wielkiego uznania, jakie musiał on budzić nawet $u$ osoby ojca świętego. We wrześniu tego samego roku powrócił jednak do Włoch, wezwany przez tego samego papieża Bonifacego VIII, aby zwalczyć Gibelinów. Durand zgodził się w imieniu papieża wymusić posłuszeństwo we wcześniej zarządzanych przez siebie prowincjach, ale dla pewności skuteczności tego poczynania został mianowany na nowo gubernatorem Romanii i Marchii Ankony ${ }^{14}$.

Musiał ciężko zachorować, ponieważ przeczuwając swoją bliską śmierć, 6 października I295 roku spisał swój testament. Udał się do Rzymu i nieco ponad rok później jego przeczucia okazały się słuszne. I listopada I296 roku Wilhelm Durand zakończył swój żywot. Został pochowany w kościele Santa Maria sopra Minerva w Rzymie, tuż obok Panteonu. Dla uczczenia jego wielkiej osoby Giovanni Cosma wykonał wspaniały gotycki grobowiec ${ }^{15}$.

Cztery lata, jakie spędził Wilhelm Durand w swojej diecezji w Mende, były jednak bardzo owocne. W Instructiones et Constitutiones odnajdujemy ślady działań duszpasterskich biskupa Mende. Dzieło to, stanowiące pewien rodzaj

\footnotetext{
I2 Por. S. della Torre, Per una lettura ..., dz. cyt., s. XII.

${ }_{13}$ Por. A. Davril, Préambule, dz. cyt., s. VIII; por. S. della Torre, Per una lettura..., dz. cyt., s. XI.

${ }^{14}$ Por. S. della Torre, Per una lettura..., dz. cyt., s. XI.

${ }_{15}$ Por. S. della Torre, Per una lettura..., dz. cyt., s. XII; por. A. Davril, Préambule, dz. cyt., s. VIII.
} 
encyklopedii, jednocześnie liturgicznej i kanonicznej, pomagało księżom zdobywać solidne wykształcenie. Prawdopodobnie również jemu zawdzięczamy redakcję Ordinarium Ecclesiae Mimatensis ${ }^{16}$.

W końcu to w czasie tych lat posługi episkopalnej tworzy dwa dzieła, które trwale naznaczą historię liturgii rzymskiej: Rationale divinorum officiorum i Pontificalis ordinis liber (I292), będący bezpośrednim przodkiem Pontificale Romanum, używanego w całym Kościele katolickim aż do niedawnej reformy liturgicznej przeprowadzonej prze Sobór Watykański II ${ }^{17}$.

Prezentując Duranda i jego metodę alegoryczną, trzeba zaznaczyć, że Rationale divinorum officiorum nie stanowi nowej wykładni XIII-wiecznej wiedzy o Kościele, ale raczej zebranie i podsumowanie całego wcześniejszego dorobku takich interpretatorów liturgii, jak Amalary, Honoriusz z Autun, Ryszard od św. Wiktora, Innocenty III, Sicard z Cremony, Wilhelm z Auxerre. To właśnie na nich Durand powołuje się w zamieszczonych przez siebie opisach ${ }^{18}$.

Dzieło Duranda powstało z troski o kapłanów i wiernych jego diecezji, dla których chciał stworzyć podręcznik, wyjaśniający szeroko podejmowane zagadnienia związane z liturgią. Chciał przybliżyć znaczenie poszczególnych miejsc, obrzędów, przedmiotów używanych w liturgii po to, by pomóc swoim diecezjanom w głębszym uczestnictwie w liturgii. Był zatem nie tylko specjalistą w swoich dziedzinach, ale wbrew pozorom także jakbyśmy to dzisiaj mogli rzecz: pastoralistą.

Dzisiejszy człowiek traktuje świątynię bardziej jako obiekt użyteczności publicznej, w którym sprawowana jest liturgia, niż jako miejsce, w którym ma dojść do jego osobistego spotkania nie tylko z Bogiem, ale i ze wspólnotą wierzących - Kościołem. Brakuje spojrzenia na świątynię jako na przestrzeń, która jest zaangażowana w liturgię, w niej bierze udział i pomaga wiernym w uczestnictwie i właściwym przeżywaniu liturgii. Trzy rozdziały pierwszej księgi napisanej przez Duranda pokazują, że przestrzeń liturgiczna nie jest martwa, że każdy jej element ma znaczenie i może pomóc człowiekowi zagłębić się w to, gdzie jest i w czym uczestniczy.

Sposób ujęcia materiału będzie oparty na metodzie hermeneutycznej. Analizie zostaną poddane trzy rozdziały pierwszej księgi Rationale divinorum officiorum [dalej: RatDivOff], w których Durand przedstawia: I) świątynię,

\footnotetext{
I6 Por. A. Davril, Préambule, dz. cyt., s. VIII.

17 Por. A. Davril, Préambule, dz. cyt., s. VIII.

I8 Por. T. Thibodeau, L'établissement de L'Apparatus ,In margine”, et l'Apparatus Fontium, w: Gvillelmi Dvranti Rationale divinorvm officiorvm I-IV, dz. cyt., s. XVI-XVII.
} 
a właściwie poszczególne elementy, które ją tworzą bądź które się w niej znajdują (RatDivOff I, I); 2); ołtarz, to, czym on jest, i co na nim lub w jego pobliżu się znajduje (RatDivOff I, 2); oraz 3) malowidła, ornamentykę i zdobienia, w jakie świątynia może być wyposażona (RatDivOff I, 3). Praca nie ma na celu przedstawienia pełnej symboliki świątyni. Autor pragnie jedynie pogrupować w logiczne zbiory to, do czego poszczególne części świątyni są przez Duranda porównywane. Poniżej zostaną przestawione dwa takie obszary: aretologia i dogmatyka.

\section{Aretologia}

W licznych elementach budowli sakralnych oraz ich własnościach biskup Mende widzi nawiązanie do cnót, czyli stałych dyspozycji człowieka do czynienia dobra. I tak wznoszenie murów kościoła to budowanie cnót, bo ,gdy my wznosimy mury Kościoła, wokół są obecni nieprzyjaciele, a mianowicie: wady albo przewrotni ludzie, pragnący powstrzymać nasze czyny”'19. Mur kościelny stanowi wyobrażenie stałej bitwy, jaką my, chrześcijanie toczymy z wrogami Kościoła. Do tej walki zostaliśmy wszakże wyposażeni w tarczę wiary, zbroję sprawiedliwości, hełm zbawienia i miecz Słowa Bożego (por. Ef 6, I4-I7).

Pod przysłowiową „lupę” Durand bierze także parametry oznaczające ideał cnót: „wysokość stanowi prawdziwą nadzieję przyszłej zapłaty, pogardzanie tym, co ma przynosić pozorne szczęście i pomyślność na rzecz oglądania Boga w krainie żyjących”º. Długość „to cierpliwość, która wyrozumiale znosi wszystko, zwracajac się ku ojczyźnie", a szerokość jest miłością bliźnego, która „rozszerza umysł przyjaciół w Bogu, a nieprzyjaciół miłuje ze względu na Boga" ${ }^{\text {"2 }}$. Wysokość i długość są parametrami mocno nacechowanymi

\footnotetext{
19 „Et nobis muros Ecclesie edificantibus adsunt in circuitu inimici, scilicet uitia siue peruersi homines, opera nostra impedire uolentes" - RatDivOff I, I, II (odtąd cyfry oznaczają kolejno księgę, rozdział, numer; tu: lib. I, cap. I, n. II).

20 „Longa lataque surgit in altum, id est in alta uirtutum [...] altitudo uero spes est future retributionis que prospera et aduersa contempnit donec uideat bona Domini in terra uiuentium"RatDivOff I, I, I5.

${ }^{21}$ „Longitudo cuius longanimitas est que patienter aduersa tolerat donec ad patriam perueniat, latitudo caritas est que dilatatione mentis amicos in Deo et inimicos diligit propter Deum" RatDivOff I, I, I5
} 
treścią eschatologiczną, otwierającą na rzeczywistość osiągnięcia obiecanej nagrody przebywania w królestwie niebieskim. Otwierają perspektywę wertykalną, podczas gdy szerokość wykazuje cechy horyzontalne, które wskazują na drugiego człowieka i budowanie relacji z nim dzięki stałej świadomości, że wszyscy jesteśmy braćmi i jednocześnie dziećmi tego samego, jedynego Boga.

Do cnót przyrównane zostają także elementy konstrukcyjne i architektoniczne: „fundamentem jest wiara, która nie pochodzi z rzeczy widzialnych”22, a przez to doskonale zna to, co jest niewidzialne. „Dachem jest miłość, która przykrywa liczne grzechy"²3, takiego też określenia użył św. Piotr w swoim liście, wzywając: „miejcie wytrwałą miłość jedni ku drugim, bo miłość zakrywa wiele grzechów” ( $\mathrm{P}$ 4, 8). „Brama jest posłuszeństwem”, wiążącym się z zachowywaniem przykazań, od których przestrzegania Jezus uzależnił osiągnięcie życia wiecznego (por. Mt I9, I7) ${ }^{24}$. „Posadzka jest pokorą, do której przylgnęła dusza" ${ }^{25}$. Durand poprzez interpretacyjny klucz posadzki jako pokory dopatruje się w niej także fundamentu naszej wiary - Chrystusa, który dla nas stał się ubogim, uniżając samego siebie, jak to określa św. Paweł w Liście do Filipian (por. 2, 8), a także innych ubogich w duchu, którzy za przykładem Chrystusa sami się uniżają. Znaczenie posadzki jako pokory podkreśla dodatkowo jej przeznaczenie. Posadzkę deptają bowiem stopy tych, którzy do kościoła wchodzą i w nim przebywają ${ }^{26}$. Na wzór czterech boków niebieskiego Jeruzalem cztery ściany boczne to cztery cnoty kardynalne: sprawiedliwość, męstwo, roztropność, umiarkowanie ${ }^{27}$.

Wnętrze świątyni również nie jest pozbawione alegorycznych odniesień do cnót. Przede wszystkim nic nie zdobi Kościoła od wewnątrz tak, jak cnoty teologalne - wiara, nadzieja i miłość. „Panie umiłowałem dom Twój ozdobny" (Ps 26 (25), 8) - zdaniem Duranda psalmista zdaje się opiewać Dom

\footnotetext{
${ }^{22}$ „In templo Dei seu gratie est fundamentum fides que est de re non uisa”- RatDivOff I, I, I6.

23 „Tectum caritas que operit multitudinem peccatorum”- RatDivOff I, I, I6.

24 „Ostium obedientia de qua Dominus inquit: «Si uis intrare in uitam serua mandata»" RatDivOff I, I, I6.

25 „Pauimentum humilitasde qua Pslamista: Adhesit pauimento anima mea”-RatDivOff I, I, I6.

26 Por. „Pauimentum ecclesie est fidei nostre fundamentum; in Ecclesia uero spirituali pauimentum sunt pauperes Christi, scilicet pauperes spiritu qui se in omnibus humiliant quare propter humilitatem pauimento assimilantur" - RatDivOff I, I, 28.

${ }^{27}$ „Quatuor laterales parietes sunt quatuor principales uirtutes, iustitia, fortitudo, prudentia et temperantia; hec sunt in Apocalypsi quatuor latera ciuitatis equlia" - RatDivOff I, I, I7.
} 
Boży ozdobiony cnotami ${ }^{28}$. Przykładem takiej roli wychwalania świątyni i samego Boga może być schola cantorum ${ }^{29}$, w której to autor widzi zgodę, wyrażającą się jednością wielu głosów, które razem, zgodnie, wyśpiewują cześć Stwórcy. Ta zgodność jest widzialnym znakiem trwania w miłości, gdyż miłość angażuje serca śpiewających do obdarowania innych poprzez śpiew odpowiednim nastrojem modlitwenym. Zdolność śpiewania jest dla niego oznaką posiadania cnoty miłości, ,ponieważ kto miłości nie ma, nie może odpowiednio śpiewać" ${ }^{30}$.

Dość ciekawą interpretację zastosował biskup Mende w odniesieniu do szklanych okien kościelnych. Najpierw wspomina, że w oknach widzi symbol gościnności z radością oraz miłosiedzia ze szczodrością ${ }^{31}$. Dalej rozwija ich znaczenie i rolę, jaką odgrywają wobec całego kompleksu architektonicznego. Bardzo zbliża je do funkcji, jaką pełnią mury świątyni. Widzi w nich księgi Pisma Świętego, „które odpychają wiatr i deszcz, to jest trzymają z dala niebezpieczeństwa, a wprowadzają do kościoła blask prawdziwego słońca, to jest Boga" ${ }^{2}$. Wnikanie tego światła do kościoła przedstawia z kolei proces docierania Słowa Bożego do serc wierzących - Boże światło rozjaśnia wszystkich przebywających w kościele. Rozwija tę myśl dodatkowo w oparciu o samą strukturę okna. W swej budowie rozszerzają się one do wewnątrz, przez co „wyrażają mistyczne zmysły ciała, które na zewnątrz muszą być opanowane, by nie czerpały kłamstw, a wewnętrznie powinny być otwarte do swobodnego czerpania darów duchowych" 3 . Tak charakterystyczna cecha konstrukcji otworów okiennych w romańskich budowlach zyskuje nie tylko praktyczne, ale i duchowe znaczenie.

${ }_{28}$ Por. „Propheta [...] ait: «Domine dilexi decorem domus tue», quam spiritualiter fides spes et caritas exornant" - RatDivOff I, 3, 4I.

29 Grupa chłopców przeznaczonych do profesjonalnego podejmowania śpiewu w czasie liturgii, zwłaszcza stacyjnej. Por. Schola cantorum, w: Leksykon liturgii, oprac. B. Nadolski, Poznań 2006, s. I454.

30 Por. „Alii chorum dixerunt a concordia que in caritate consistit quia qui caritatem non habet conuenienter cantare non potest" - RatDivOff I, I, I8.

${ }^{3}$ „Fenestre sunt hospitalitas cum hilaritate et misericordia cum largitate, de hac domo Dominus ait: «Ad eum ueniemus et mansionem apud eum faciemus»" - RatDivOff I, I, I7.

32 Por. „Fenestre ecclesie uitree sunt Scripture diuine que uentum et pluuiam repellunt, id est nociua prohibent, et dum claritatem ueri solis, id est Dei, in ecclesiam”- RatDivOff I, I, 24.

33 Por. „Hee intus latiores sunt quia misticus sensus amplior est et precellit litteralem; item per fenestras quinque sensus corporis significantur qui extra stricti esse debent ne uanitates hauriant et intus patere ad dona spiritualia liberius capienda" - RatDivOff I, I, 24. 
Aretologicze znaczenie mają również stopnie prowadzące do ołtarza: ,przez te schody odpowiednio są rozumiane cnoty, wznoszą się do ołtarza, to jest Chrystusa" ${ }^{3}$. Tę myśl zaczerpnął Durand bezpośrednio z Pisma Świętego, z Psalmu 84, gdzie każdy następny stopień pomaga doświadczyć swoistego wzrostu, nie tyle wysokościowego wiążącego się z fizycznym wznoszeniem ku górze, ile wewnętrznego podbudowania: „Z mocy w moc wzrastać będą: Boga nad bogami ujrzą na Syjonie" (Ps 84 (83), 8). Stopnie symbolizują też piętnaście cnót, bo piętnaście stopni znajdowało się w świątyni Salomona, co z kolei stanowi nawiązanie do piętnastu psalmów śpiewanych u stopni ołtarzowych ${ }^{35}$. Pieśni stopni, to inaczej „pieśni” pielgrzymów - były to psalmy od I20 (II9) do I34 (I33), które śpiewali pielgrzymi zdążający do świętego miasta - Jeruzalem, a zwłaszcza na górę Syjon, wyrażając swoją tęsknotę i pragnienia zbliżenia się do Pana ${ }^{36}$.

Ołtarz wewnętrzy świątyni Salomona symbolizował nasze serce - ,przez ołtarz bowiem jest rozumiane nasze serce" ${ }^{37}$. To rozumowanie jest stosunkowo proste, ponieważ chcąc znaleźć właściwe odniesienie dla ołtarza znajdującego się we wnętrzu świątyni jerozolimskiej, Speculator musiał znaleźć równie istotny i znaczący punkt odniesienia. Raczej nic nie odpowiada tej świętej budowli tak dobrze, jak przyrównanie jej do równie świętego miejsca, posługując się terminologią zaczerpniętą od św. Pawła Apostoła, jakim jest świątynia naszego ciała, w której mieszka sam Bóg (por. I Kor 3, I6-I7). Czymś najświętszym, a zarazem znajdującym się we wnętrzu tej świątyni, jest właśnie nasze serce.

Istotne miejsce $\mathrm{w}$ tym porównaniu znajduje także odniesienie do spalania ofiar, a więc zestawienie ognia - towarzyszącego obrzędowi całopalenia do cnoty miłości. „Ogień jest miłością, ołtarz jest naszym czystym sercem, ogień zawsze będzie płonął na ołtarzu, ponieważ miłość zawsze będzie rozpalać nasze serce" ${ }^{\prime 8}$. Tę interpretację Durand zaczerpnął z Pieśni nad

34 „Per hos ergo gradus competenter uirtutum gradus intelliguntur quibus ad altare, id est Christum, ascenditur" - RatDivOff I, 2, I3.

35 Por. RatDivOff I, 2, I3.

${ }_{3} 6$ Por. przypis do wersetu Ps I20, I, w: Pismo Święte Starego i Nowego Testamentu w przekładzie z języków oryginalnych (Biblia Tysiąclecia), opracował zespół biblistów polskich $\mathrm{z}$ inicjatywy Benedyktynów tynieckich, wydanie piąte na nowo opracowane i poprawione, Poznań 2003, s. 694; a także: M. Ostrowski, Nabożeństwo w drodze, s. 4, http://www.pastoralna. pl/files/308\%20Nabozenstwo\%20w\%20drodze.pdf (I7.0I.20I4).

37 „Per altare enim cor nostrum intelligitu” - RatDivOff I, 2, IO.

$3^{8}$,Ignis est caritas, altare est cor nostrum mundum; ignis semper ardebit in altari quia caritas semper feruebit in corde nostro" - RatDivOff I, 2, II. 
Pieśniami, gdzie jest mowa o tym, że „,wody wielkie nie zdołają ugasić miłości” (Pnp 8, 7). Skoro ołtarz jest naszym sercem, na którym możemy składać ofiary całopalenia, to też ,z serca muszą wychodzić czyny, rozpalone ogniem miłości”. Wszystko zależne jest więc od miłości. Na potwierdzenie postawionej przez siebie tezy autor odowłuje się do św. Pawła, który w Pierwszym Liście do Koryntian, w swoim Hymnie o miłości, nazywa ową „,miłość drogą doskonałą” a zarazem pełnią wszystkich cnót i stwierdza, iż „ktokolwiek ją ma, ma wszystkie cnoty"39.

„Ołtarz jest naszym sercem, na którym możemy składać ofiary” człowieka jest najwłaściwszą formą ołtarza, ponieważ sam Jezus powiedział, że Bóg jest duchem i chce, aby Jego czciciele oddawali Mu cześć w duchu i prawdzie (por. J 4, 24). Tylko ołtarz, utożsamiony z sercem, może służyć właściwemu ofiarowaniu i właściwie rozdzielać (chleb). Biskup Mende dokonuje jednak rozróżnienia, kiedy składamy ofiary w sposób właściwy, a kiedy w sposób niewłaściwy. „Właściwie ofiarujemy, kiedy dobro, które mamy na myśli doprowadzamy do doskonałości’"4ı. Niewłaściwe ofiarowanie wiąże się z niepoprawnym rozdzielaniem chleba. Choć nie odwołuje się tutaj wprost do św. Pawła, w zapisanym przez niego zdaniu: ,często człowiek zamierza dobro, a czyni zło, i często czyni dobro, a z innej strony czyni zło, i tak oto ten sam człowiek buduje i ten sam niszczy", daje się słyszeć słowa Apostoła Narodów z Rz 7, I5-2I ${ }^{42}$. Ostatecznie Speculator stwierdza, że człowiek właściwie rozdziela daną ofiarę wtedy, kiedy dobro, które czyni, przypisuje nie sobie, lecz jedynemu Bogu ${ }^{43}$.

W trzecim rozdziale pierwszej księgi Rationale... Durand ponownie nawiąże do ołtarza oznaczającego serca człowieka. W sercu człowieka, tak jak

\footnotetext{
39 "Quicumque ipsam habet omnes uirtutes habet” - RatDivOff I, 2, II.

40 "Altare est cor nostrum in quo debemus oferre" - RatDivOff I, 2, 6.

${ }^{41}$ „Recte offerimus quando bonum quod cogitamus ad perfectionem perducimus” RatDivOff I, 2, 6.

$4^{2}$ „Nie rozumiem bowiem tego, co czynię, bo nie czynię tego, co chcę, ale to, czego nienawidzę - to właśnie czynię. Jeżeli zaś czynię to, czego nie chcę, to tym samym przyznaję Prawu, że jest dobre. A zatem już nie ja to czynię, ale mieszkający we mnie grzech. Jestem bowiem świadom, że we mnie, to jest w moim ciele, nie mieszka dobro; bo łatwo przychodzi mi chcieć tego, co dobre, ale wykonać - nie. Nie czynię bowiem dobra, którego chcę, ale czynię to zło, którego nie chcę. Jeżeli zaś czynię to, czego nie chcę, już nie ja to czynię, ale grzech, który we mnie mieszka. A zatem stwierdzam w sobie to prawo, że gdy chcę czynić dobro, narzuca mi się zło" (Rz 7, I5-2I).

43 Por. RatDivOff I, 2, 6.
} 
na ołtarzu, winna być składana, poprzez skruchę, ofiara prawdziwej wiary. Postawa skruchy to w gruncie rzeczy najcenniejszy złoty haft, zdobiący ołtarz naszego serca. Właśnie taki złoty haft, jakim jest skrucha, jako wynik dobrej pracy przemawia i wskazuje, „w jaki sposób powinniśmy ozdobiać nasze czoło, aby zajaśniało dla innych"ł4. Wizję złotego haftu zaczerpnął on ze Starego Przymierza, gdzie w Księdze Wyjścia Mojżesz daje wytyczne dotyczące budowy ołtarza. Wspomina, że ma on być ozdobiony szerokim wieńcem: „Zbudujesz mi ołtarz i uczynisz mu dookoła wieniec na wysokość czterech palców"45. Tak powinniśmy zdobić złotym haftem miłości nasze czoło, żebyśmy przygotowani byli oddać dusze dla Chrystusa ${ }^{46}$.

Zdaniem biskupa Mende prawdziwy ołtarz, ten wewnętrzny, może Bogu zbudować jedynie ten, „kto zdobi swój [ołtarz] prawdziwą pokorą i innymi cnotami" ${ }^{47}$. Na potwierdzenie przytacza słowa papieża Grzegorza Wielkiego: „Kto gromadzi cnoty bez pokory, ten jakoby kurz niósł przeciw wiatrowi”ł ${ }^{\text {. }}$. Przez ołtarz rozumie jednocześnie każdą duszę, która jest budowana przez Pana z żywych kamieni, a są nimi różne cnoty ${ }^{49}$.

$\mathrm{Z}$ cnotliwym życiem wiąże się też interpretacja świeczników umieszczanych na ołtarzu. Są one potrzebne do tego, by mogły jaśnieć dobrymi czynami. Świecznik ulokowany na zewnątrz ,jest czynem dobrym, ponieważ innych zapala przez dobry przykład"so. Ma to swoje potwierdzenie w Ewangelii według św. Łukasza: „Nikt nie zapala światła i nie stawia go w ukryciu ani pod korcem, lecz na świeczniku, aby jego blask widzieli ci, którzy wchodzą" (Łk II, 33). Lampa dająca światło jest też ukazaniem dobrej intencji, bo skoro światłem dla ciała jest jego oko, i tylko zdrowe oko może pozwolić ciału stanąć

44 Por. „Nempe altare quandoque significat cor hominis in quo sacrificium uere fidei per contritionem offerri debet, et tunc aurifrisium conceptum bone operationis significat quo frontem nostram ornare debemus ut ceteris luceamus" - RatDivOff I, 3, 32.

$45 \mathrm{Wj}$ 25, 25: „I uczynisz wokoło listwę na cztery palce szeroką i zrobisz wieniec złoty dokoła dla tej listwy”, albo Wj 37, 2: „I pokrył ją szczerym złotem wewnątrz i zewnątrz, i uczynił na niej dokoła złoty wieniec".

46 Por. RatDivOff I, 3, 32.

47 „Hoc altare ille edificat qui suum uera humilitate aliisque uirtutibus exorant” - RatDivOff I, 2, IO.

48 „Unde Gregorius: «Qui uirtutes sine humilitate congregat quasi qui puluerem, contra uentum portat»" - RatDivOff I, 2, IO.

49 Por. ,Vel per altare uniuscuiusque animam intelligimus que edificatur Domino ex lapidibus uiuis uariis et diuersis" - RatDivOff I, 2, II.

50 „Candelabrum exterius illuminans est opus bonum quod alios per bonum exemplum accendit" - RatDivOff I, 2, 8. 
w świetle, czyli prawdzie (por. Łk II, 34), to oko może wykazać prawdziwość naszych intencji. „Nie powinniśmy więc kłaść lampy pod korcem, lecz na świeczniku, ponieważ jeśli mamy dobrą intencję, nie musimy jej ukrywać, lecz dobry czyn dla innych w świetle i przykładzie czynić widzialnym"5.

Nawiązaniem do cnót są także tkaniny, które pokrywają ołtarz. Obrus, którym przykrywa się mensę ołtarzową, a w sposób szczególny jego biel, dowodzi czystości, a jednocześnie świadczy o tym, że czyny przyobleczonego w taką samą biel będą czyste, co nasz autor zaczerpnął z Księgi Koheleta: „Każdego czasu niech szaty twe będą białe” (Koh 9, 8). Dalej tłumaczy: „odziewa się ołtarz tkaninami czystymi i białymi, ponieważ serce czyste jest ozdabiane dobrymi czynami’’52. Opis tkanin na ołtarzu nie ogranicza się jedynie do lnianych obrusów. Durand wspomina także inne tkaniny, podkreślając zarazem ich świętość: „tkaniny jedwabne położone na ołtarzu są różnymi ozdobami cnót, którymi jest ozdabiana dusza"s3.

Każda niedziela przypomina o tym, że chrześcijanin przeżywa radość ze zmartwychwstania Chrystusa. Nawet niedziele Wielkiego Postu nie są pozbawione tego znaczenia, gdyż jak pisze: „,nigdy nie było czasu, w którym nie było radości wiecznej”’54, dlatego też nie pościmy w niedziele ${ }^{55}$. Przez dni powszednie okresu Wielkiego Postu prezbiterium jest skrywane za zasłonami, ponieważ one ukazują, że ukształtowana radość wieczna jest osłaniana przez niebo, tak jak tkaniny zasłaniające niejako prezbiterium, czyli będzie osiągalna dopiero w niebie ${ }^{56}$. Natomiast na niedzielę zasłony są rozsuwane bądź podnoszone, i to już na nieszpory odbywajace się w sobotę, tak by wszyscy mogli podziwiać chwałę nieba poprzez patrzenie na sanktuarium, które przypomina prawdę zmartwychwstania Pańskiego ${ }^{57}$.

\footnotetext{
${ }^{5}$ „Non debemus ergo ponere lucernam sub modio sed super candelabrum, quoniam si habemus bonam intentionem non debemus abscondere sed bonum opus aliis in lumen et exemplum manifestare" - RatDivOff I, 2, 8.

$5^{2}$ „Rursus albis et mundis pannis operitur altare quando cor mundum bonis operibus adorantur" - RatDivOff I, 2, I2.

53 „Pallea uero serica super altare posita sunt diuersarum uirtutum ornamenta quibus anima decorata est" - RatDivOff I, 2, I2.

54 „Quia nulla fuit etas in qua non fuerit gaudium eternum”- RatDivOff I, 3, 37.

55 Por. „Inde est quod diebus dominicis non ieiunamus” - RatDivOff I, 3, 37.

${ }_{56}$ Por. „Gaudium quidem figuratum quod celo uelatur, quod per uelum illud significatur” RatDivOff I, 3, 37.

57 Por. „Verumptatem uelum quod diuidit sanctuarium a clero retrahitur uel eleuatur in uespera cuiuslibet sabbati Quadragesime, quando officium diei dominice inchoatur ut cle-
} 
Poszczególne niedziele Wielkiego Postu niosą także dodatkowe upamiętnienia radości. Pierwsza niedziela wspomina tę radość, którą mieli pierwsi nasi rodzice zanim popadli w grzech (por. Rdz 2, 7-3, 24). Druga obrazuje radość, którą mieli nieliczni w arce Noego, kiedy wszyscy inni zostali zatopieni przez potop na skutek prowadzenia grzesznego życia (por. Rdz 6, 5-9, I7). Trzecia przypomina tę, którą mieli synowie Izraela (Jakuba), kiedy inni za czasów jego syna Józefa doświadczeni zostali głodem (por. Rdz 45, I-47, 3I). Czwarta niedziela jest tą radością, którą posiadali żyjący w pokoju pod panowaniem Salomona (por. I Krl 5, I-I4). Piąta tą, którą mieli powracający z niewoli babilońskiej (por. Ezd i Neh). Szósta zaś niedziela tą, którą mieli uczniowie od zmartwychwstania aż do wniebowstąpienia, kiedy był z nimi Oblubieniec (por. Mt 28, 9-20; Mk I6, I2-I9; Łk 24, I2-52; J 20, I- 2I, 23) ${ }^{58}$.

Przy wzmiance o zasłonach Speculator czyni także pewne wyjaśnienie historyczne. Zaznacza, że teraz, kiedy w okresie Wielkiego Postu wypada jakiś dzień świąteczny, to zasłony podobnie jak w niedziele są otwierane bądź podnoszone. „Lecz nie ma to praktyki w pierwotnym funkcjonowaniu Kościoła, ponieważ wtedy żadnego święta nie obchodzono uroczyście w Wielkim Poście. Jeśli jakieś święto wypadało, w jakimkolwiek by dniu nie wypadało, czyniono jego pamiątkę w sobotę i w niedzielę"59. Dzieje się tak ze względu na smutny charakter tego okresu. Wyjaśnia równocześnie, że potem praktyka taka została wycofana, a obchodzone święta w okresie Wielkiego Postu zaczęto celebrować w ich właściwym dniu, i to wraz ze zwolnieniem od zachowywania postnego charakteru dnia ${ }^{60}$.

Kontynuując zagadnienie zasłon i tkanin, Durand wyjaśnia, jakie jest ich znaczenie. Są one rozkładane w kościołach w różne święta przede wszystkim dla ozdoby, abyśmy przez widzialne zodobienie zostali poruszeni do tego, co niewidzialne ${ }^{61}$. Nie bez znaczenia pozostają także zastosowane kolory. Różnorodność użytych barw ma ukazać człowiekowi, że jak upiększa się świątynię ziemską, tak on sam, będąc świątynią Boga, ma być zdobiony

rus possit in sanctuarium intueri, quia dominicam recolit resurectionem" - RatDiVOff I, 3,36 .

\footnotetext{
$5^{8}$ Por. RatDivOff I, 3, 37.

59 „Sed hoc non habetur de primaria Ecclesie institutione quia tunc nullum festum celebratur in Quadragesima sollempniter. Sed si aliquod festum occurrebat, quacumque die occurreret, in sabbati et in dominica de eo commemoratio fiebat" - RatDivOff I, 3, 38 .

6o Por. RatDivOff I, 3, 38 .

${ }_{61}$ Por. „Ut per uisibiles ornatus ad inuisibiles moueamur” - RatDivOff I, 3, 39.
} 
wielobarwnymi cnotami ${ }^{62}$. I tak poszczególne cnoty odpowiadają poszczególnym wartościom: zasłona biała odpowiada czystości życia, zasłona czerwona - miłości, zielona - kontemplacji, barwa czarna nawiązuje do umierania cielesnego, a liliowa do udręczenia. Ważne jest także ich umiejscowienie ponad jasnymi zasłonami, gdyż w ten sposób zostaje podkreślone, że nasze serce musi się stale oczyszczać z wad po to, by nabierać przed Bogiem prawdziwej jasności. Podobny efekt zostaje osiągnięty poprzez wieszanie różnych kawałków tkanin, co niekedy również się spotyka. Różnorodność zasłon ma odpowiadać temu, co ma przepełniać człowiecze serce - musi ono obfitować w szereg cnót, jak i dobre uczynki ${ }^{63}$.

Biskup Mende wspomina ponadto o trzech znanych mu zwyczajach dekorowania świątyni na święta Bożego Narodzenia. Pierwszy polega na tym, że na wspominanie tajemnicy wcielenia kościoły nie są przyozdabiane w żadne tkaniny. Dzieje się tak dlatego, by zobrazować nasze poczucie wstydu. Chociaż największą radością są narodziny Zbawiciela, to jednak nie możemy przez to zapominać, że okrywa nas wstyd, ponieważ nasz grzech jest rzeczywiście wielki. Powinien być w nas wstyd, że Pan musiał poniżyć samego siebie, że przyjął postać sługi (por. Flp 2,6-7) i poniósł śmierć za nas, sam będąc bez grzechu. Stąd też podejmujemy ostry post na wspomnienie Jego śmierci, świętując bez radości, inaczej niż na pamiątkę ,śmierci różnych świętych, kiedy to powinniśmy się radować i nieco pobłażać w pożywaniu i piciu"64. Święci, w przeciwieństwie do Jezusa, cierpieli nie za nasze grzechy, ale podejmowali cierpienie i przyjmowali śmierć ze względu na Chrystusa.

Ci, którzy zdobią świątynie w skromniejsze tkaniny na święta Bożego Narodzenia, podobnie podkreślają służebną postawę Chrystusa, ale też czynią tak dlatego, by oddać rzeczywistość groty, w której Zbawiciel przyszedł na świat. Został owinięty w małowartościowe pieluszki, bo nie było dla Niego nigdzie indziej miejsca (por. Łk 2, 7). Tam zaś, gdzie wiesza się dostojne tkaniny, czyni się to w celu ukazania radości z narodzin prawdziwego Króla. Bogactwo tych materiałów ma pobudzić nas do przyjęcia właściwej postawy wobec przychodzącego Boga. W przeciwieństwie do mieszkańców

\footnotetext{
${ }_{62}$ Por. „Homo qui Dei templum ornatus esse debet uarietate seu diuersitate uirtutum” RatDivOff I, 3, 39.

63 Por. RatDivOff I, 3, 39.

${ }_{64}$ Por. „Cum tamen in aliorum sanctorum obitu leti sollempnizemus et aliquantulum latius in cibis et potu nobis indulgeamus" - RatDivOff I, 3, 40.
} 
Betlejem z czasów Jego narodzin, powinniśmy Mu okazać gościnę i przyjąć tak wielkiego Gościa do siebie ${ }^{65}$.

Speculator wielokrotnie podkreśla, że bogactwo i kosztowność materiałów, z jakich wykonuje się tkaniny, szaty i naczynia liturgiczne, oraz inne utensylia ołtarzowe są po to, aby spełnić nasz ludzki moralny obowiązek wobec Tego, który jest dawcą wszelkiego dobra i względem Kogo żywi się prawdziwą miłość. To również zapowiedź dla nas, ukazująca radość z przebywania w przyszłości w niebie przed Jego Boskim majestatem. Bogactwo tych wszystkich przedmiotów ma ukazać piękno i różnorodność cnót, jakimi powinni błyszczeć kapłani i to wszystko, czego używają w czasie świętej liturgii ${ }^{66}$.

$\mathrm{W}$ przyklasztornym ogrodzie, zapewne zasobnym w różnego gatunki drzewa i krzewy, pełnym kwiatów, owoców i jarzyn, Durand dopatruje się alegorii nagromadzenia cnót ${ }^{67}$.

\section{DOGMATYKA}

\section{Chrystologia}

W alegorii stosowanej przez Duranda przede wszystkim dominuje chrystologia. Pierwszym elementem budowli sakralnej utożsamionej z osobą Zbawiciela, jaki Speculator wymienia w swoim dziele, jest kamień węgielny ${ }^{68}$. Porównanie to ma źródło biblijne, zostało zaczerpnięte z Ef 2, 20, gdzie chrześcijanie zostają przedstawieni jako domownicy Boga mieszkający w domu, którego „kamieniem węgielnym jest sam Chrystus Jezus". Zasadniczo cała świątynia oznacza także Chrystusa, skoro w wybudowanych ścianach Durand widzi „Żydów i narody, które przychodzą do Chrystusa z czterech części świata"69. Absyda świątyni, która wieńczy ją od strony wschodniej, również stanowi poparcie

\footnotetext{
${ }_{65}$ Por. RatDivOff I, 3, 40.

66 Por. RatDivOff I, 3, 46.

${ }_{67}$ Por. „Hortus arborum et herbarum, congeries uirtutum” - RatDivOff I, I, 43.

68 „Hec est domus Domini firmiter edificat cuius fundamentum est angularis lapis Christus” - RatDivOff I, I, 9 oraz: „Ipse [Christus] enim est lapis angularis” - RatDivOff I, 3, 3I. ${ }^{69}$ „Super edificati parietes Iudeisunt et gentiles de quatuor mundi partibus ad Christum uenientes" - RatDivOff I, I, 9.
} 
tej wizji, gdyż dla Duranda „oznacza wierzących świeckich, przyłączających się do Chrystusa i Kościoła”7o. W końcu „Bóg wznosi sobie świątynię z żywych kamieni i drewna niepodlegającego zniszczeniu [...] to jest Chrystus ze świętymi jaśniejącymi czystością"71. Chrystus to także przedsionek (kruchta) kościoła, ponieważ to przez „Niego jest otwarte wejście do niebieskiego Jeruzalem" "72. On stanowi okazały portyk, czy też bramę, zgodnie z tym, co sam o sobie powiedział: „Ja jestem bramą” (J IO, 9) ${ }^{73}$.

Chrystologiczne znaczenie Speculator nadaje również samej bryle świątyni. Najbardziej popularnemu w średniowieczu modelowi oparcia świątyni na planie krzyża przypisuje znaczenie kommemoratywne, mianowicie tłumaczy to następująco: „Pewne bowiem kościoły są ukształtowane na planie krzyża dla zaznaczenia, że my jesteśmy ukrzyżowani przez świat"74. Drugim wytłumaczeniem dla tego planu przestrzennego świątyni jest przypomnienie o tym, że jako wierzący jesteśmy zobowiązani iść za Ukrzyżowanym. To stwierdzenie ma oczywiście swoje źródło w Ewangelii, gdzie Jezus mówi: „kto chce pójść za Mną, niech się zaprze samego siebie, niech weźmie krzyż swój i niech Mnie naśladuje" (Mt I6, 29). Plan koła, jaki również występował w historii, uzyskuje znaczenie ewangelizacyjne, gdyż wobec Kościoła Chrystus postawił zadanie rozszerzania się Dobrej Nowiny po całym świecie, takie też zadanie zlecił Chrystus swoim apostołom: „Idźcie na cały świat i głoście Ewangelię wszelkiemu stworzeniu" (Mk I6, I5). Durand w tej misji posłania apostołów widzi realizację słów zapisanych w Psalmie I9: ,ich głos się rozchodzi po całej ziemi, ich słowa aż po krańce świata" (Ps I9 (I8), 5). Plan koła niesie w sobie również znaczenie eschatologiczne, ponieważ krąg ziemi, na którym żyjemy i który zdobywamy dla Chrystusa, ma nas doprowadzić do osiągnięcia innego kręgu - wieńca zwycięstwa, korony wieczności ${ }^{75}$.

70 „Absida [...] significat fideles laicos Christo et Ecclesie inherentes”- RatDivOff I, I, I9.

${ }_{71}$ „Deus enim Ecclesiam sibi construit uiuis ex lapidibus et lignis imputribilibus [...], id est Christus de sanctis castitate candidatis" - RatDivOff I, I, 3I.

${ }^{72}$ „Atrium ecclesie significat Christum per quem in celestem Ierusalem patet ingressus”RatDivOff I, I, 20.

73 Por. „Ostium ecclesie Christus est” - RatDivOff I, I, 26.

74 „Quedam tamen ecclesie in modum crucis formantur ad notandum nos mundo crucifigi seu crucifixum sequi debere" - RatDivOff I, I, I7.

75 Por. „Nonnulle etiam in modum circuli rotunde formantur que significant Ecclesiam dilatatam esse per circulum orbis, unde illud: «Et in fines orbis terre uerba eorum», seu quod de circulo orbis perueniemus ad circulum corone eternitatis" - RatDivOff I, I, I7. 
Alegoria chrystologiczna znajduje zastosowanie najczęściej przy opisie ołtarza. „Ołtarz bowiem symbolizuje Chrystusa”7 - po dzień dzisiejszy jest to jeden z najczytelniejszych symboli Chrystusa ${ }^{77}$. Oznacza on Chrystusa, gdyż bez Niego niemożliwością byłoby przyjęcie jakiegokolwiek daru przez Ojca. Chrystus składa zatem dar z tego, kim jest i powierza go swemu Ojcu, samemu stając się jednocześnie Kapłanem, ale i Ofiarą. Chrystus jest kapłanem swojej własnej ofiary: ,przez Ducha wiecznego złożył Bogu samego siebie jako nieskalaną ofiarę" (Hbr 9, I4). Wynika z tego, zgodnie z I Tm 2, 578, że Kościół wznosi swoje modlitwy do Ojca wyłącznie przez Chrystusa. To potwierdzenie jedynego pośrednictwa Chrystusa, o którym Kościół wypowie się w Katechizmie Kościoła Katolickiego w XX wieku w ten sposób: „Jezus Chrystus jest prawdziwym Bogiem i prawdziwym człowiekiem w jedności swojej Osoby Boskiej; z tej racji jest On jedynym Pośrednikiem między Bogiem i ludźmi” (480).

Na ołtarz jako na Chrystusa wskazuje również zdobienie ołtarza drogocennymi tkaninami. Poprzez złoty haft symbolicznie zostaje przedstawiona ozdoba miłości. „Jak bowiem złoto przewyższa wszystkie metale, tak i miłość przewyższa inne cnoty, jak u apostoła w Pierwszym Liście do Koryntian: «Największa z nich jest miłość»»" (I3, I3b) ${ }^{79}$. Jak tkaniny okrywające ołtarz są zdobione złotym haftem, tak nasze czoła powinny być zdobione złotym haftem miłości, ,żebyśmy byli przygotowani oddać dusze dla Chrystusa"80.

Kolory odgrywają również istotną rolę w czymś tak prozaicznym, jak tkanina nakrywająca ołtarz. Speculator wspomina o zwyczaju nakrywania ołtarza trzema tkaninami na Paschę, co stanowi wykazanie ponadczasowości misji Chrystusa i ukazaniu Go jako Tego, który jest ponad Prawem (por. Rz 7, 4-6). Pierwsza wierzchnia narzuta koloru czarnego jest zdejmo-

${ }^{76}$ Por. „[...] altare etiam, quod Christum significat” - RatDivOff I, I, 39; „Per hos ergo gradus competenter uirtutum gradus intelliguntur quibus ad altare, id est Christum, ascenditur" - RatDivOff I, 2, I3.

77 „W każdym kościele powinien być ołtarz stały, jasno i trwale wskazujący na Jezusa Chrystusa, który jest Żywym kamieniem" - Ogólne wprowadzenie do Mszału rzymskiego, Poznań 2004, 298.

${ }^{8}$ Por. „Albowiem jeden jest Bóg, jeden też pośrednik między Bogiem a ludźmi, człowiek, Chrystus Jezus, który wydał siebie samego na okup za wszystkich" (I Tm 2, 5-6).

79 „Sicut enim aurum preeminet omnibus metallis, sic et caritas ceteris uirtutibus munde Apostolus ad Corinthios I: «Maior autem horumest caritas»" - RatDivOff I, 3, 32.

8o Por. „Frontem enim nostram sic aurifrisio caritatis ornare debemus ut parati simus pro Christo animas ponere" - RatDivOff I, 3, 32. 
wana, gdy kończy się pierwsze czytanie. Symbolizuje ona czas przed Prawem. Po drugim czytaniu i responsorium jest zdejmowana kolejna - tym razem biaława, która oznacza czas trwania Prawa. Wraz z zakończeniem trzeciego czytania usuwana jest trzecia narzuta, koloru czerwonego, symbolizująca czas łaski, w którym przez mękę Chrystusa zostało nam otowrzone wejście do wiecznej chwały świętych ${ }^{81}$.

Durand stopniowo zawęża się w semantyce ołtarza. Ołtarz jest też symbolem Ciała Chrystusa ${ }^{82}$. Taką interpretację przedstawiał już Optat z Mileve, żyjący w IV wieku biskup tego miasta. W dziele Contra Parmenianum Donatistam przedstawił on ołtarz nie w kluczu typologicznym, dopatrując się w ołtarzu formy, ale raczej miejsca czy siedziby Ciała i Krwi Chrystusa ${ }^{83}$. Ciało bądź pokorę Zbawiciela, wyrażają „,białe lniane obrusy, którymi ołtarz jest okrywany" ${ }^{4}$. Skąd takie zawężenie? Mamy tu do czynienia z dość szeroką interpretacją, która odwołuje się do procesu uzyskiwania bieli. Proces ten był efektem żmudnej pracy i wysiłku, a to pomagało dopatrzeć się znaczenia wysiłku i trudu podejmowanego przez Jezusa podczas Jego działalności. Chrystus przez swoje wcielenie porzucił niebiańskie światło i radość, by przez liczne udręczenia (tutaj znajduje swoje odwołanie owa praca i wysiłek) dojść do zmartwychwstania, ,przez które Syn rozradował Ojca"85. Widzimy tutaj zatem wpływ dogmatu o wcieleniu Chrystusa i jego konsekwencji - zjednoczeniu duszy i ciała Chrystusa: „ubrany zatem ołtarz jest duszą nieśmiertelną i niezniszczalną złączona z ciałem" ".6 . Chrystologiczna interpretacja obrusów i ich analogia do tajemnicy wcielenia prowadzi do tego, że zdjęcie obrusów w Wielki Piątek jest znakiem żałoby i smutku, wyraża bowiem rozdzielenie duszy od ciała Chrystusa, a zatem jest obrazem Jego śmierci ${ }^{87}$.

W interpretacji biskupa Mende ołtarz wewnętrzny, umieszczony we wnętrzu świątyni jerozolimskiej, zapowiadał już wcielenie Chrystusa i wyrażał wiarę w tę prawdę. Przez to, że w świątyni jerozolimskiej ofiary wieczorne składano na ołtarzu wewnętrznym, to już sama pora złożenia ofiary przenosi

\footnotetext{
8I Por. RatDivOff I, 3, 4I.

82 Por. „Altare [...] significat corpus Domini” - RatDivOff I, 2, 3.

${ }_{3}$ Por. J. Mieczkowski, J. Superson, Teologiczne usytuowanie ottarza w świątyni chrześcijańskiej, „Collectanea Theologica” 78 (2008) nr I, s. II6.

${ }_{4}$ Por. „Porro linteamina alba quibus operitur altare carnem siue humilitatem saluatoris designant" - RatDivOff I, 2, I2.

85 Por. RatDivOff I, 2, I2.

86 „Altare ergo uestiri est animam immortali et incorruptibili corpori iungi”- RatDivOff i, 2, I2.

87 Por. RatDivOff I, 2, I3.
} 
nas na Golgotę, gdzie na ołtarzu krzyża Chrystus dokonał najdoskonalszej ofiary i złożył samego siebie.

Durand ogromne znaczenie przywiązuje do kielicha. Cytuje kilka perykop ukazujących znaczenie i wartość tego naczynia: „Babilon był w ręku Pana złotym kielichem, upajającym całą ziemię” (Jr 5I, 7), „Kielich pełen czystego wina w domu Pana mieszam” (Ps 75 (74), 9), „Podniosę kielich zbawienia i wezwę imienia Pańskiego” (Ps II6 (II5), I3), „Czy możecie pić kielich, który Ja mam pić?” (Mt 20, 22), „wziąwszy kielich odmówił dziękczynienie..." (Mt 26, 27). Różne znaczenie przybiera kielich ze względu na tworzywo, z jakiego jest wykonany. I tak ,złoty kielich oznacza skarby mądrości ukryte w Chrystusie, srebrny [kielich oznacza] oczyszczenie winy, zrobiony ze stopu srebra i ołowiu (cynowy) wyraża podobieństwo winy i kary" ${ }^{88}$. Dość trudnym wytłumaczeniem jest uzasadnienie wykonania kielicha: „Stop [metali] jest czymś pomiędzy srebrem a ołowiem, a ciało Chrystusa, chociaż nie było z ołowiu, a więc [ciałem] grzesznym, to jednak było ciałem podobnym grzesznemu, i chociaż nie było ze srebra, to znaczy [ciałem] cierpiącym za swoje grzechy, to jednak [Chrystus] cierpiał za nasze [grzechy], ponieważ obarczył się naszymi słabościami, «On sam dźwigał nasze boleści»»" (Iz 53, 4) ${ }^{89}$. Łączenie metali w przypadku kielicha zdaje się być zatem zabiegiem, który ukazuje, że Chrystus przyjął na siebie ludzkie ciało, takie jakie posiada każdy człowiek, skłonne do cierpienia, które i Jemu nie było obce, jak i skłonne do grzeszenia, jednak On był ponad tę własność. Chrystus przyjął nasze ciało, aby obarczony naszymi krzywdami i zranieniami, móc za nie przecierpieć i nas podźwignąć z upadku, gdyż sam nie mając grzechu, nie mógł nieść żadnej swojej słabości.

Nie brakuje również porównania Chrystusa do światła, które jest zapalone w kościele ${ }^{90}$, do Ewangeliarza, który o Nim świadczy, a który jest umieszczany na ołtarzu ${ }^{91}$, oraz do znaku Jego chwalebnego zwycięstwa - krzyża ${ }^{92}$.

${ }^{88}$ „Calix autem aureus significat thesauros sapienitie in Christo absconditos, argenteus munditiam culpe, stagneus innuit similitudinem cuple et pene" - RatDivOff I, 3, 45.

${ }_{89}$ „Stagnum enim est medium inter argentum et plumbum, et caro Christi licet non fuerit plumbum, id est peccatrix, fuit tamen carni similis peccatrici; et licet non fuerit argenteum, id est passibilis propter suam culpam, fuit tamen passibilis propter nostram, quia «languores nostros ipse tulit et dolores nostros ipse portauit»” - RatDivOff I, 3, 45.

90 Por. „Lumen quod in ecclesia accenditur Christum significat” - RatDivOff I, I, 40.

9I Por. „Codex etiam euangelicus super illud adaptatur, eo quod euangelium ab ipso, scilicet Christo, sit editum et ipsi perhibeat testimonium”- RatDivOff I, 3, 33.

92 Por. „Crux autem in altum dirigitur per quod Christi uictoria designatur” - RatDivOff I, I, 4I. 
Jednak na podkreślenie zwycięstwa Chrystusa nie stosuje się tylko wyobrażenia krzyża. Także wznoszące się nad ołtarzem sztandary przypominają Jego triumf. Wymowa sztandaru jest na dodatek pedagogiczna, gdyż przez triumf, jaki odniósł nasz Zbawiciel, również i my mamy nadzieję odnieść zwycięstwo nad nieprzyjacielem ${ }^{93}$.

Z kolei pamiątką zmartwychwstania Chrystusa jest zwyczaj podnoszenia zasłony zakrywającej sanktuarium tuż przed sobotnimi nieszporami Wielkiego Postu, które rozpoczynają świętowanie niedzieli. To nawiązanie do przedarcia się zasłony przybytku w świątyni jerozolimskiej w chwili śmierci Chrystusa na krzyżu i jednocześnie pamiątka wydarzenia, które otworzyło przed nami bramę królestwa niebieskiego i dało moc do przezwyciężania pożądliwości cielesnych ${ }^{94}$.

\section{Pneumatologia}

Trzecia Osoba Trójcy Przenajświętszej, Duch Święty, ukazuje swoją rolę w znaku wody, gdyż ona spaja ze sobą wapno i piasek, tworząc solidną zaprawę. Zaprawa ta łączy ze sobą kamienie, dzięki czemu powstają mury świątyni czyli wiernych ${ }^{95}$. Duch Święty jest właśnie taką wodą, która łącząc różne tworzywa, symbolizujące różnych ludzi, czyniąc z nich jedno. „Gorące wapno jest miłością, która się łączy z piaskiem" ${ }^{96}$. To On pobudza do miłości, bez której ludzie nie byliby w stanie stabilnie budować niebieskiego Jeruzalem ${ }^{97}$.

93 Por. „Vexilla etiam super altare eriguntur, ut triumphus Christi iugiter in ecclesia memoretur per quem et nos de inimico triumphare speramus" - RatDivOff I, 3, 32 .

94 Por. „In Parasceue uero omne tollitur uelum, quia in passione Domini uelum templi scissum est et per eam reuelata est nobis legis spiritualis intelligentia que antea latebat, ut premissum est, et aperta est celestis regni ianua et data est nobis fortitudo ut uinci, nisi uelimus, a carnali concupisecentia nequeamus. Verumptatem uelum quod diuidit sanctuarium a clero retrahitur uel eleuatur in uespera cuiuslibet sabbati Quadragesime, quando officium diei dominice inchoatur ut clerus possit in sanctuarium intueri, quia dominicam recolit resurectionem" - RatDivOff I, 3, 36.

95 Por. ,Vt autem calx et terra ad edificium muri ualeant, aque commixtione conglutinantur, siquidem aqua Spiritus sanctus est; [...] sine cemento lapides muri non simul iunguntur ad muri stabilitatem" - RatDivOff I, I, IO.

96 „Calx feruens caritas est que sibi coniungit sabulum, id est terrenum opus”- RatDivOff I, I, IO.

97 Por. ,[...] sic nec homines ad edificium celestis Ierusalem possunt simul sine caritate iungi quam Spiritus sanctus operatur" - RatDivOff I, I, IO. 
Duch Święty przyczynia się do tego, by wierni po trudach zabiegania o niebo, które obrazuje budowa świątyni ziemskiej, znaleźli w końcu odpoczynek i schronienie w niebieskim Jeruzalem.

Symboliczną liczbę siedmiu kolumn opisywanych przy budowie Przybytku w starotestamentalnym Pięcioksięgu Speculator interpretuje jako siedem darów Ducha Świętego, którymi muszą być umacniani biskupi ${ }^{8}$. To również mocno biblijna interpretacja, wyjęta z Księgi Proroka Izajasza, która przedstawia siedem darów Ducha Świętego: „I spocznie na niej Duch Pański, duch mądrości i rozumu, duch rady i męstwa, duch wiedzy i bojaźni Pańskiej. Upodoba sobie w bojaźni Pańskiej”(Iz II, 2-3)99. Ta sama interpretacja - siedmiu darów Ducha Świętego - dotyczy również siedmiu lamp umieszczanych w kościele. Duch dzięki darom pochodzącym od Niego rozświetla ciemności naszego życia, naszej ślepoty. Lampy te umieszcza się na świeczniku, ponieważ ten sam Duch zstąpił na Jezusa podczas chrztu w Jordanie i umocnił Go tymi darami, aby mógł spełniać powierzoną Mu przez Ojca misję głoszenia wolności wszystkim, którzy doświadczają jakiegokolwiek uwięzienia ${ }^{100}$.

Także ołtarz zewnętrzny, ustawiony w świątyni jerozolimskiej, ma swoje odniesienie do Parakleta, jako sprawcy nawrócenia i Tego, który swoją mocą niweluje wszelkie pokusy. Ołtarz ,jest znakiem umierania naszego serca, w którym cielesne dążenia są niszczone przez działanie Ducha Świętego"ıor. Najwyższy ołtarz jest zaś odwołaniem do Trójjedynego Boga ${ }^{102}$.

$9^{8}$ „Columpne plures sint, tamen septem esse [...] quoniam episcopi esse debent septiformi gratia Spiritus sancti repleti" - RatDivOff I, I, 27.

99 Może dziwić fakt, że Księga Izajasza wymienia sześć darów Ducha, a nie siedem. W tekście Iz II, 2-3a jest mowa o sześciu darach, gdyż dar bojaźni Bożej występuje dwukrotnie w wierszach 2b i za. Tradycja Kościoła głosząca siedem darów Ducha opiera się na Septuagincie, która występujące dwa razy te same hebrajskie określenia przetłumaczyła dwoma różnymi słowami (eusebeia oraz phobos Kyriou), a także na Wulgacie, przypisywanej św. Hieronimowi, która podaje również dwa odmienne określenia: pietas oraz timor, dzięki czemu mamy w obecnej formie dwa różne dary Ducha Świętego: pobożność i bojaźń Bożą. Por. K. Romaniuk, O siedmiu darach Ducha Świętego, Warszawa I992, s. 8-9.

100 Por. „Fecit quoque Moyses lucernas septem, que sunt septem dona Spiritus sancti que in nocte huius seculi tenebras nostre cecitatis illustrant, que super candelabra ponuntur quia requieuit supra Christum spiritus sapienite et intellectus, spiritus consilii et fortitudinis, spiritus scientie et pietatis, spiritus timoris Domini, quibus predicauit captiuis indulgentiam" - RatDivOff I, I, 40.

го „Rursus altare est mortificatio nostra seu cor nostrum in quo carnales motus feruore Spiritus sancti consumintur" - RatDivOff I, 2, 3 .

102 Por. „Altare superius est Deus Trinitas” - RatDivOff I, 2, 3. 
Nawet tak niepozorne narzędzia, jakimi są szczypce do świec albo kleszcze do ucinania knotów, mają swoje alegoryczne znaczenie. I to takie, które pomaga człowiekowi na odkrycie Ducha. Durand twierdzi, że są one słowami Bożymi, którymi odcinamy literę prawa, a odkrywamy światło Ducha ${ }^{103}$, według tego: „Będziecie jedli zboże z dawnych zapasów, a kiedy przyjdą nowe zbiory, usuniecie dawne zapasy" (Kpł 26, I0). Te nożyce pomagają zatem poznać Stary Testament i jednocześnie spojrzeć nań w świetle Nowego, poddać go weryfikacji i odkryć właściwe znaczenie.

\section{Mariologia}

Ciekawe znaczenie alegoryczne przypisuje Durand zakrystii: symbolizuje ona łono Najświętszej Maryi. Skąd takie porównanie? Jest ono owocem już nieco głębszej refleksji. Żeby to zrozumieć, trzeba najpierw zastanowić się nad funkcją zakrystii. Stanowi ona miejsce, w którym są składane różne świętości (warto tutaj przypomnieć, że we wczesnym średniowieczu to właśnie w tym pomieszczeniu - sacrarium - było przechowywane Ciało Pańskie, zanim rozwinął się zwyczaj przechowywania go w tabernakulum od ok. IX wie$\mathrm{ku}^{\mathrm{I04}}$ ). Także w tym pomieszczeniu kapłan przywdziewał święte szaty, co ma miejsce po dzień dzisiejszy. Te dwie cechy owego pomieszczenia sprawiły, że średniowieczni alegoryści dopatrywali się w nim łona Najświętszej Maryi, bo to właśnie w nim „Chrystus przyodział się w święte ubranie ciała”, i tak jak kapłan wychodzi stąd do ołtarza, tak „Chrystus przyszedł na świat, wychodząc $\mathrm{z}$ łona Dziewicy"105.

Nie tylko pomieszczenie, jakim jest zakrystia, może służyć skierowaniu myśli ku Bogarodzicy. Także puszka, w której konsekrowane są hostie, oznacza dla Duranda ciało chwalebnej Dziewicy, o której jest mowa w Psalmie: „Wyrusz Panie, na Twój odpoczynek, Ty i Twoja arka pełna twojej

103 Por. „Emunctoria, siue forcipes ad emungendum licinia, sunt uerba diuina quibus litteram legis amputamus et lucentem spiritum reuelamus, iuxta illud: «Vetustissima ueterum comedetis et nouis superuenientibus uetera abicietis»" - RatDivOff I, 3, 28.

104 Por. Tabernakulum, w: Leksykon liturgii, dz. cyt., s. I555.

105 „Sacrarium siue locus in quo sacra reponuntur, siue in quo sacerdos sacras uestes induit, uterum sacratissime Marie significat in quo Christus se sacra ueste carnis uestituit. Sacerdos a loco in quo uestes induit ad publicum procedit quia Christus, ex utero Virginis procedenes, in mundum uenit" - RatDivOff I, I, 38 . 
chwały" (Ps I32 (I3I), 8) ${ }^{\mathrm{I06}}$. Werset tego psalmu może nawiązywać do podróży Maryi w góry do pewnego miasta, w którym mieszkała Elżbieta z Zachariaszem, a które tradycja łączy z miastem Ain-Karim ${ }^{107}$. Ewangelista Łukasz podaje, że zaraz po zwiastowaniu Maryi przez archanioła Gabriela, iż stanie się Matką Zbawiciela, udała się ona z pośpiechem odwiedzić krewną - Elżbietę, o której dowiedziała się od anioła, że również jest w stanie błogosławionym, i to pomimo jej podeszłego wieku (por. Łk I, 39-45). Maryja już od chwili przyzwolenia na wolę Bożą względem niej stała się brzemienna i z Chrystusem obecnym pod swym sercem idzie pomóc krewnej, stając się prawdziwą Arką niosącą Boga. Dlatego biskup Mende puszkę eucharystyczną służącą do przechowywania i przenoszenia Ciała Pańskiego skojarzył z osobą Matki Najświętszej, która nosiła Chrystusa w swoim łonie.

\section{Eschatologia}

Średniowiecze przykładało ogromne znaczenie do wszystkiego, co odnosiło się do Paruzji, czyli powtórnego przyjścia Chrystusa na ziemię. Życie po śmierci w królestwie Chrystusa bądź potępienie w ogniu piekielnym determinowały nie tylko zagadnienia podejmowane przez kaznodziejów, ale i te pojawiające się w życiu codziennym, wśród najbardziej prozaicznych czynności bądź rozmów. Doświadczenie grzechu i widmo zaciąganej przez niego kary wiecznej było stale obecne w świadomości ludzi średniowiecza. To także nawoływanie do nawrócenia i wzywania do bycia gotowym na powrót Pana, na czasy, kiedy Chrystus zatriumfuje w pełni swego majestatu. I od takiej wizji Kościoła, będącego zapowiedzią przyszłej rzeczywistości, wychodzi Durand.

Tłumacząc różne nazwy stosowane na określenie Kościoła, rozumianego zarówno jako rzeczywistość założona przez Chrystusa, jak i obiekt kultyczny, biskup Mende pisze, że Kościół obecnie jest nazywany Syjonem ze względu na oczekiwanie. Nawiązuje w ten sposób zarówno do Izraelitów wychodzących z niewoli egipskiej i pielgrzymujących do Ziemi Obiecanej (por. Wj I3, IO-II), jak i do tęsknoty Narodu Wybranego przebywającego w niewoli babilońskiej, opłakującego Syjon i zbudowaną na nim

106 Por. „Et nota quod capsa in qua hostie consecrate conseruantur significat corpus Virginis gloriose de qua dicitur in Psalmo: «Surge Domine in requiem tuam, tu et archasanctificationistue»" - RatDivOff I, 3, 25.

107 Przypis do wersetu Łk I, 39, w: Pismo Święte..., dz. cyt., s. I203. 
świątynię (por. Ps 137 (I36), I-5). Aspekt pielgrzymowania pomaga Durandowi dostrzec w Kościele obraz wydarzeń przyszłych, pozwala przedstawić to, czego chrześcijanie oczekują, wyglądają: ,przez utrwalone długotrwałe pielgrzymowanie [Kościół] dostrzega obietnicę oglądania rzeczy niebieskich, i z tego powodu otrzymał nazwę Syjon, to jest oczekiwanie/wyglądanie"ro8. „Ze względu na oczekiwany pokój” Durand określa Kościół mianem Jerozolimy. „Jeruzalem jest interpretowane jako obraz pokoju”。o9. Sama nazwa „Jerozolima” oznacza zresztą „Miasto Pokoju”. Królestwo Boże, które nastanie na ziemi wraz z paruzją, przyniesie światu prawdziwy pokój, nastanie wtedy Nowe Jeruzalem. Tak też mamy powiedziane w Apokalipsie św. Jana Apostoła: „I Miasto Święte - Jeruzalem Nowe ujrzałem zstępujące z nieba od Boga, przystrojone jak oblubienica zdobna w klejnoty dla swego męża. I usłyszałem donośny głos mówiący od tronu: «Oto przybytek Boga z ludźmi: i zamieszka wraz z nimi, i będą oni Jego ludem, a On będzie Bogiem z nimi” (Ap 2I, 2-3).

Kościół określa też Durand nazwą Namiotu Boga, czyli ruchomego „sanktuarium", jakie stworzył Mojżesz dla Pana w czasie wędrówki Izraelitów przez pustynię. Widzi w tym oczywistą analogię, tłumaczy, że „w teraźniejszym życiu [Kościół] jest w drodze i [jest] pielgrzymującym, podążając do ojczyzny”"IIo. Wyczekiwanie rzeczywistości niebieskiej jest więc ważnym odniesieniem, dzięki któremu Speculator zyskuje wiele nazw określających Kościół. Sam ruchomy przybytek, wykonany w drodze jest też dla niego symbolem tego świata, a zwłaszcza jego przemijalności. Durand odwołuje się tutaj do Pierwszego Listu św. Jana Apostoła - ziemski świat przemija wraz z wszystkimi jego pożądliwościami (por. I J 2, I7a) ${ }^{\text {II }}$. Ukazuje w ten sposób, że Kościół na ziemi nie jest tym ostatecznym, ale zapowiedzią tego, który ma się urzeczywistnić w niebie.

Przybytek stanowi także symbol Kościoła walczącego, który jak zaznacza Durand zgodnie z autorem Listu do Hebrajczyków, „tu na ziemi nie ma trwałego miasta, lecz szuka tego, które ma przyjść" (Hbr I3, I4). Dalej pisze, że „przybytki są dla walczących, bo Bóg jest w przybytku”, tzn. Bóg

\footnotetext{
108 Por. „Dicitur etiam presens Ecclesia Syon, eo quod ab hac peregrinatione longe posita promissionem rerum celestium speculatur, et ideo Syon, id est speculatio, nomen accepit" RatDivOff I, I, 4.

Io9 Por. „Pro futura uero patrie pace Ierusalem uocatur, nam Ierusalem uisio pacis interpretatur" - RatDivOff I, I, 4.

Iо „Quandoque Dei tabernaculum quia in presenti uita peregrina est et in itinere ad patriam pergens ut iam dicetur" - RatDivOff I, I, 4.

II Por. „Tabernaculum autem, quia in itinere factum, quandoque gerit typum mundi qui transit et concupiscentia eius" - RatDivOff I, I, 6.
} 
jest pośród tych, którzy gromadzą się w Jego Imię - jest siłą i potęgą tej twierdzy ${ }^{112}$. Biskup Mende pisze również, że przybytek łatwo przekształcić w świątynię, „ponieważ od służby wojskowej zwraca się ku tryumfowi”"I3. Kościół tu na ziemi toczy walkę, ale w niebie odnosi wspaniałe zwycięstwo i niekończący się tryumf.

Nie zabrakło również bezpośredniego porównania. Kościół materialny, w którym gromadzi się lud, aby chwalić Boga, oznacza święty Kościół, który jest budowany w niebie z żywych kamieni. Dom Pana jest wznoszony jako silny, ponieważ budowany jest na trwałym fundamencie, na kamieniu węgielnym, którym jest Chrystus. Na Nim to został położony fundament apostołów i proroków (por. Ef 2, 20) ${ }^{\mathrm{IL}}$. Ściany tego gmachu stanowią wierni przeznaczeni do życia, to oni są kamieniami użytymi do budowy tego muru. Mur ten jednak jest stale wznoszony, aż do końca świata, bo wyznawców Chrystusa stale przybywa ${ }^{115}$. W przypadku kościoła materialnego kamienie nie uzyskają łączności między sobą, jeśli nie zostaną powiązane przy pomocy zaprawy murarskiej. Na tej samej zasadzie wierni zjednoczeni w jeden Lud Boży, dla budowania niebieskiego Jeruzalem, są łączeni ze sobą poprzez zaprawę miłości. Tą zaprawą miłości jest Duch Święty, który pobudza wszystko do istnienia i jest twórcą jedności ${ }^{116}$.

Sama bryła świątyni, jej plan również obrazuje eschatologię, zwłaszcza wówczas, kiedy jest wykonana na planie koła. Świątynia tak uformowana

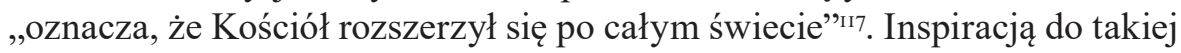

II2 Por. „Expressim uero tabernaculum typum gerit Ecclesie militantis que non habet hic manentem ciuitatem sed futuram inquirit, ideoque dicitur tabernaculum, tabernacula enim militantium sunt; Deus ergo in tabernaculo Deus est in fidelibus suo nomine congregatis" RatDivOff I, I, 6.

"13 Por. „Tabernaculum uertitur in templum quia de militia curritur ad triumphum”RatDivOff I, I, 6.

${ }^{I 14}$ Por. „Siquidem ecclesia materialis in qua populus ad laudandum Deum conuenit sanctam significat Ecclesiam que in celis uiuis ex lapidibus construitur. Hec est domus Domini firmiter edificat cuius fundamentum est angularis lapis Christus super quo fundamento positum est fundamentum apostolorum et prophetarum" - RatDivOff I, I, 9.

"I5 Por. „Fideles autem ad uitam predestinati sunt lapides in structura huius muri qui semper usque in finem huius mundi edificabitur - RatDivOff I, I, 9.

II6 Por. „Sicut enim sine cemento lapides muri non simul iunguntur ad muri stabilitatem, sic nec homines ad edificium celestis Ierusalem possunt simul sine caritate iungi quam Spiritus sanctus operatur" - RatDivOff I, I, IO.

${ }^{\text {II7 }}$, ,Ecclesiae] in modum circuli rotunde formantur que significant Ecclesiam dilatatam esse per circulum orbis, unde illud: «Et in fines orbis terre uerba eorum»" - RatDivOff I, I, I7. 
interpretacji był werset 5 Psalmu 19: ,ich głos się rozchodzi na całą ziemię i aż po krańce świata ich mowy". Krąg ma znaczenie kosmiczne i przenosi do rzeczywistości niewidzialnej, stąd Durand tłumaczy taki model kościoła również w taki sposób: „z kręgu ziemskiego dojdziemy do kręgu korony wieczności" "II8. Wierni wchodzący do świątyni na planie okręgu mają poczuć, że wchodzą w rzeczywistość nieba, że zostają w nią wręcz porwani i wyniesieni do stanu nieśmiertelności.

Także w samych parametrach świątyni, przede wszystkim w jej wysokości, Speculator dopatruje się nadziei przyszłej zapłaty dla tych, którzy pogardzili tym, co przynosi szczęście w rozumieniu ziemskim, na rzecz spełnienia ważniejszego pragnienia - oglądania Boga w krainie żyjących ${ }^{11}$. Na nadzieję przyszłej chwały otwiera ponadto wystrój świątyni. Wszelkie kosztowne materiały upiększające świątynie ukierowują myśli wiernych w stronę nieba, i Liturgii tam sprawowanej. Dbałość o wystrój i zastosowanie kosztownych materiałów Durand określa nawet mianem „obowiązku moralnego spełnianego wobec miłości Bożej”'20. Dekoracja i zdobienia ukazują chwałę, do jakiej my zmierzamy, a w jakiej przybywa Bóg wraz z wszystkimi świętymi i aniołami. Do wspomnianych aniołów nawiązują dwa chóry śpiewających psalmy w kościołach. Oznaczają one aniołów i dusze sprawiedliwych, które swymi głosami wychwalają naprzemiennie Boga. Ich postawa zachęca również wiernych patrzących na ich modlitwę do dobrego działania i złożenia dobrej ofiary ${ }^{121}$.

\section{Eklezjologia}

\section{a) Wizje Kościoła}

Kościół dla Biskupa Mende nie jest czymś hermetycznie zamkniętym. To rzeczywistość, która jest otwarta i poszukuje stale nowych członków wśród róż-

\footnotetext{
II8 „Quod de circulo orbis perueniemus ad circulum corone eternitatis" - RatDivOff I, I, I7.

II Por. ,[...] longa lataque surgit in altum, id est in alta uirtutum [...] altitudo uero spes est future retributionis que prospera et aduersa contempnit donec uideat bona Domini in terra uiuentium" - RatDivOff I, I, I5.

${ }^{120}$ „Preterea hec diuine pietatis official moralia sunt et future glorie significatiua” RatDivOff I, 3, 46.

${ }^{121}$ Por. „Duo ergo chori psallentium designant angelos et spiritus iustorum quasi reciproca uoce laudantium et se ad bonam operationem inuicem exhortantium" - RatDivOff I, I, I8.
} 
nych warstw i grup społecznych. W sposób prosty obrazuje to przyrównaniem Kościoła do nierządnicy, „a to z tego powodu, że Kościół zbudowany został z narodów" i przez tę wielość i różnorodność, narażoną na grzech, sprzeniewierzenie i niewierność, „nikomu nie zamyka powrotu do siebie, na swe łono" "122. Kościół jest dla niego społecznością, „bo stanowi wspólnotę świętych obywateli”"223. Tym, co tych obywateli wyróżnia, jest księga Pisma, wokół której się gromadzą. Więź z tą Księgą jest na tyle mocna, że stają się „obwarowaną twierdzą" broniącą tego cennego skarbu przed heretykami ${ }^{124}$.

Durand wykazuje ciągłość Przymierza, które zawarł Bóg z Narodem Wybranym. Wskazuje jednak, że Stare Przymierze nie osiągnęło pełni, która dopiero miała nadejść wraz z Nowym: „Cokolwiek bowiem Synagoga przyjęła przez prawo, to teraz Kościół przez Chrystusa, którego jest Oblubienicą, przyjął dzięki łasce i zmienił na lepsze" ${ }^{25}$. Przyjście Chrystusa i Jego zbawcze dzieło przynosi nowe światło przemieniające całą rzeczywistość.

W samym układzie świątyni biskup Mende dopatruje się części ludzkiego ciała - prezbiterium, gdzie umieszczony jest ołtarz, stanowi głowę, transept to ramiona i ręce, a nawa to reszta tułowia. Powiela jednak jeszcze interpretację Ryszarda od św. Wiktora, który w planie kościoła dostrzega pewną trójdzielność. Trzem przestrzeniom świątyni odpowiadają kolejne stany: sanktuarium - stan dziewictwa, chór - stan wstrzemięźliwości, nawa - stan małżeński. Kluczem do takiego rozróżnienia jest wielkość tych przestrzeni przekładająca się odpowiednio albo na ówczesne mniemanie co do poziomu świętości tych stanów, albo na liczebność i popularność wskazanych stanów: przestrzenie mniej pojemne odnoszą się do stanów o mniejszej liczebności ${ }^{126}$.

Omawiając zasłanianie poszczególnych miejsc w kościele oraz różnego typu dekorację na czas przeżywania okresu Wielkiego Postu, Durand wspo-

122 Por. „Quandoque [Ecclesia dicitur] meretrix figuratur propter Ecclesiam de gentibus congregatam et quia nulli claudit gremium redeunti ad se" - RatDivOff I, I, 4.

I23 „Quandoque uocatur ciuitas, propter communionem sanctorum ciuium”- RatDivOff I, I, 4.

${ }^{124}$ Por. „Murata propter munitionem Scripturarum quibus heretici arcentur, habens lapides et ligna diuersi generis quia diuersa sunt merita singulorum prout iam dicetur" - RatDivOff I, I, 4 .

I25 „Quicquid autem Synagoga per legem accepit, hic nunc Ecclesia a Christo, cuius sponsa est, per gratiam recepit et in melius commutauit" - RatDivOff I, I, 4.

${ }^{126}$ Por. ,[...] sanctuarium enim significat ordinem uirginum, chorus continentium, corpus coniugatorum. Strictius enim est sanctuarium quam chorus et chorus quam corpus quia pauciores sunt uirgines quam continentes et isti quam coniugati; sacratior quoque est locus sanctuarii quam chorus, et chorus quam corpus, quia dignior est ordo uirginum quam continentium, et illorum coniugatorum" - RatDivOff I, I, I4. 
mina jeszcze jedno rozróżnienie poszczególnych części świątyni, o którym świadczą rozmieszczane w niej zasłony. I ta czynność nie jest taka zwyczajna. „W kościele jest wieszana zasłona trojakiego rodzaju”227. Pierwsza zasłona to ta, która okrywa świętość - jest ona znakiem prawa. Druga zasłona, która oddziela sanktuarium od duchowieństwa, wyobraża naszą niegodność oglądania tego, co należy do samego Boga. Trzecia, która oddziela duchowieństwo od ludu, symbolizuje powściągliwość cielesnej przyjemności ${ }^{128}$.

Zasłony rozciągane po obu bokach ołtarza umożliwiają dyskretne wejście kapłana do prezbiterium. Według Speculatora są one pamiątką zasłony, którą Mojżesz zakrywał swoją twarz, ilekroć wchodził przed oblicze Pana (por. Wj 34, 33-35). Zaznacza, że działo się tak, ponieważ ,synowie Izraela nie mogli wytrzymać jasności jego oblicza"'29. Księga Wyjścia podaje, że Mojżesz, schodząc z góry Synaj, zakrywał swoje oblicze, żeby zebrani u stóp góry Izraelici nie widzieli, jak znika z jego oblicza blask, którym był okryty podczas rozmowy z Bogiem. Najwyraźniej obawiał się tego, by ludzie nie dostrzegli powrotu jego twarzy do normalnego wyglądu, bo wówczas mogliby pomyśleć, że podobnie tymczasowy czy przejściowy charakter będzie posiadać Prawo, które Mojżesz miał im ogłosićt ${ }^{130}$. Tak interpretuje to zdarzenie św. Paweł w trzecim rozdziale Drugiego Listu do Koryntian (por. 3, 4-I8). Durand, powołując się zresztą na tę perykopę, zauważa, że ,jak mówi Apostoł, ta zasłona po dziś jest na sercach Żydów" (por. 2 Kor 3, I5) ${ }^{131}$.

Prawo starotestamentowe opromieniały blask i chwała, jednak była to skromna chwała w porównaniu z dostojeństwem posługi nowotestamentowej. Nowa ekonomia zbawienia wyraźnie przyćmiła swoją chwałą Stary Testament. Te dwie ekonomie zbawienia mają się do siebie tak, jak to, co przemijające, do tego, co niezmienne i trwałe ${ }^{132}$. Izraelici nie rozpoznali nadejścia Mesjasza, i dlatego Durand, cytując za św. Pawłem, pisze: „stępiały ich umysły [bo], aż po dzień dzisiejszy, gdy czytają Stare Przymierze, pozostaje nad nimi ta zasłona, bo odsłania się ona w Chrystusie" (2 Kor 3, I4). Księgi Starego

\footnotetext{
${ }^{127}$ „Notandum est quod triplex genus ueli suspenditur in ecclesia” - RatDivOff I, 3, 35.

${ }^{128}$ Por. RatDivOff I, 3, 35.

${ }^{129}$ Por. „Corine que ab utroque altaris latere extenduntur sacerdote secretum intrante” RatDivOff I, 3, 35.

${ }^{130}$ Por. Komentarz praktyczny do Nowego Testamentu, t. 2, red. A. Jankowski, K. Romaniuk, L. Stachowiak, Poznań-Kraków I999, s. I80.

${ }^{131}$ „Et sicut dicit Apostolus hoc uelamen adhuc hodie est super corda Iudeorum”RatDivOff I, 3, 35.

${ }^{132}$ Por. Komentarz praktyczny do Nowego Testamentu, t. 2, dz. cyt., s. I80.
} 
Testamentu są dla Żydów ciągle zakryte ponieważ nie umieją zdobyć się na ich właściwe odczytanie. Nie chcą zrozumieć, że całe Stare Przymierze jest ukierunkowane ku Chrystusowi, i że jak kiedyś z woli Bożej zasłona okrywała oblicze Mojżesza, tak Żydzi sami, dobrowolnie przesłonili sobie niejako i oczy, i serca, aby nie dostrzec i nie odczuć tego wszystkiego, czego dokonał Jezus ${ }^{133}$.

Zasłona rozciągana przed ołtarzem w czasie officium mszalnego w Wielkim Poście, nawiązująca do zasłony ze świątyni jerozolimskiej, wyraża oddzielenie Miejsca Świętego od Miejsca Najświętszego ${ }^{134}$. Arka Przymierza umieszczona za tą zasłoną (por. Wj 26, 33) była niewidoczna dla ludzi, bo stanowiła najcenniejszy skarb - znak Bożej obecności. Zasłona ta była bogato zdobiona. Księga Wyjścia podaje wskazania do jej wykonania: „Zrobisz też zasłonę z fioletowej i czerwonej purpury, z karmazynu i z kręconego bisioru, z cherubami wyhaftowanymi przez biegłego tkacza" (Wj 26, 3I). Z historii liturgii wiemy, że tzw. zasłony postne, okrywające nie tylko krzyże i przedstawienia pasyjne, ale właśnie i ołtarz czy nawet całe prezbiterium, wyrażały uczucie solidarności wiernych z tymi, którzy odbywają publiczną pokutę i wyczekują Wielkiego Czwartku ${ }^{135}$ i pojednania się z Kościołem - podkreślając w ten sposób świadomość grzeszności u wszystkich wierzących ${ }^{136}$. Zdaniem Duranda stanowiła zapowiedź męki Pańskiej, poprzez którą zasłona „rozwarła się"137, co ma nawiązywać do chwili, w której Zbawiciel wyzionął ducha, a zasłona przybytku rozdarła się na dwoje (por. Mt 27, 5I). Rozdarcie zasłony skrywającej Miejsce Najświętsze jest uznawane w tradycji chrześcijańskiej za zniesienie kultu Mojżeszowego i otwarcie przybytku mesjańskiego poprzez zbawczą śmierć Chrystusa ${ }^{138}$.

\footnotetext{
${ }_{133}$ Por. Komentarz praktyczny do Nowego Testamentu, t. 2, dz. cyt., s. I80.

${ }^{134}$ Por. RatDivOff I, 3, 35.

${ }^{135}$ W centrum rzymskiej tradycji Wielkiego Czwartku znajdowało się pojednane pokutników. Por. M. Kunzler, Liturgia Kościoła, przeł. L. Balter, Poznań 1999, s. 644 (Amateca. Podręczniki Teologii Katolickiej, Io). W Wielki Czwartek sprawowano trzy msze święte - pierwszą była msza święta sprawowana przez biskupa w kościele katedralnym, w czasie której konsekrował on krzyżmo święte i błogosławił oleje katechumenów oraz chorych. Druga msza również była sprawowana przez biskupa w kościele katedralnym, ale podczas niej miał miejsce obrzęd pojednania wszystkich pokutujących. Te dwie msze wchodziły jeszcze do okresu Wielkiego Postu, natomiast trzecia sprawowana w tym dniu w każdym kościele - Msza Wieczerzy Pańskiej - stanowiła już początek Triduum Paschalnego.

${ }^{136}$ Por. Zastona postna, w: Leksykon liturgii, dz. cyt., s. I726.

${ }^{137}$ Por. RatDivOff I, 3, 35.

${ }_{138}$ Por. Przypis do wersetu Mt 27, 5I, w: Pismo Święte..., dz. cyt., s. II78.
} 
Speculator wspomina jeszcze trzeci rodzaj zasłon. Ich opis nastręcza interpretatorom nie lada trudności i pozwala na przynajmniej trzy interpretcje, mające swój początek w pierwotnym Kościele, w którym stosowano tzw. peribo$\operatorname{los}^{139}$. Peribolos to greckie określenie na balustradę, którą na Zachodzie określano łacińskim terminem cancelli. Było to ogrodzenie, które wyznaczało miejsce święte, jakiś konkretny wyjątkowy pod względem świętości i znaczenia obszar. W starożytnym, pogańskim Rzymie taka bariera miała przede wszystkim sens praktyczny, oddzielający rzymskich urzędników od tłoczących się petentów. W kościele była to specjalna bariera w formie ogrodzenia, ograniczająca dostęp do grobu męczennika, która wskazywała, że dana przestrzeń jest wyłączona $\mathrm{z}$ użytku świeckiego (profanum) ${ }^{\mathrm{I}}$. W takim znaczeniu biskup Mende mógł myśleć o umieszczaniu bogato zdobionych zasłon właśnie na takiej przegrodzie.

Równie dobrze może chodzić o nawiązanie do ścian, które otaczały prezbiterium kościoła typu pielgrzymkowego, a na których wieszano ozdobne tkaniny. Durand albo odwołuje się do kościołów, w których powstał ambit, czyli obejście wokół prezbiterium (chóru) odzielone od niego murem bądź arkadami, powstałe w wyniku przedłużenia naw bocznych, często otoczone od strony zewnętrznej wieńcem kaplic promienistych ${ }^{14}$; albo też odwołuje się do takiej organizacji prezbiterium, pod którym znajdowałaby się krypta (Confessio lub Martyrium), podwyższająca dodatkowo poziom prezbiterium i wynosząca je znacznie ponad poziom nawy. Do krypty, w której umieszczano najczęściej relikwie jakiegoś świętego, prowadziły schody umiejscawiane po bokach prezbiterium bezpośrednio z ambitu lub naw (tak bocznych, jak i nawy głównej) bądź bezpośrednio z nawy głównej, pozostawiając środkową część na wejście do prezbiterium ${ }^{142}$ (taką sytuację mamy np. w bazylice św. Cecylii na Trastevere w Rzymie bądź w zbarokizowanej bazylice św. Marka w Rzymie), albo odwrotnie - środkiem czyniono zejście do krypty, a po bokach wychodzono do prezbiterium (drugą wersję możemy podziwiać z kolei w bazylice św. Wawrzyńca za Murami w Rzymie).

\footnotetext{
${ }^{139}$ Por. RatDivOff I, 3, 35.

${ }^{140}$ Por. B. Nadolski, Misterium chrześcijańskiego oltarza, Kraków 2009, S. I7I.

${ }^{\mathrm{I}} \mathrm{I}$ Por. W. Koch, Style w architekturze. Arcydzieła budownictwa europejskiego od antyku po czasy wspótczesne, przekł. W. Baraniewski i in., koordynator przekł. L. Krzyżanowski, Warszawa I996, s. 433, nr I09 „chór”.

${ }^{142}$ Por. W. Durandus, J. M. Neale, B. Webb, The symbolism of Churches and Churches Ornaments a translation of the first book of the „Rationale Divinorum Officiorum” written by William Durandus sometime bishop of Mende with an Introductory essay and notes, London I906, s. 58, przypis 8I.
} 
Pierwsze znaczenie zdaje się mieć najlepsze uzasadnienie, zwłaszcza kiedy weźmiemy pod uwagę wysokość takiego peribolos oraz jego funkcję odgrodzenia duchownych znajdujących się w prezbiterium od świeckich przebywających przed tymi balaskami w nawie. Durand mógł więc zaznaczyć, że ozdobne zasłony umieszczone na cancelli (peribolos) służyły pobudzeniu wiernych do gorliwszej modlitwy i czerpania dobrego przykładu, gdyż patrząc na nie, mogli oni obserwować w dalszej perspektywie, jak duchowni śpiewali w prezbiterium psalmy, oddając się modlitwie ${ }^{\mathrm{T} 43}$.

Durand kilkakrotnie podkreśla, że zasłona spełnia głównie zadanie rozdzielania duchowieństwa od ludu, tak żeby wzajemnie na siebie nie patrzyli, gdyż dostrzega w tym posłuszeństwo słowom psalmu: „Odwróć twe oczy, niech nie patrzą na marność" (Ps II9 (II8), 37) ${ }^{\mathrm{I} 44}$. Wymowne jednak stają się te dni, w których zasłony są podniesione albo nieobecne. I tak w Wielki Piątek, kiedy rozdarła się zasłona w świątyni, ,zostało nam objawione rozumienie prawa duchowego, które przedtem było ukryte" ${ }^{445}$. Została wtedy otwarta przed nami brama królestwa niebieskiego, ale również i siła, byśmy potrafili przezywciężyć pożądliwość cielesną, i to nawet pomimo naszej niechęci ${ }^{146}$. Dzieje się tak też zawsze przed sobotnimi nieszporami Wielkiego Postu na znak rozpoczęcia officium niedzielnego, które jest pamiątką zmartwychwstania ${ }^{147}$. Do ścian bryły świątyni Durand przyrównuje Żydów i inne narody, które na skutek Ewangelii przylgnęły do Chrystusa. W konsekwencji ścianami świątyni, jej murem, są także ci, którzy uwierzyli w Chrystusa „albo wierzą i będą wierzyć; wierni bowiem są przeznaczeni do życia [jako] kamienie w budowli tego muru, który zawsze aż do końca tego świata będzie wznoszony" "148. W tej niezwykłej inwestycji każdy ma swój wkład, każdy na swój sposób angażuje się

\footnotetext{
I43 Por. „Quod ideo fiebat ut populus uidens clerum psallentem inde bonum sumeret exemplum" - RatDivOff I, 3, 35.

${ }^{144}$ Por. RatDvOff I, 3, 36.

${ }^{145}$ „Et per eam reuelata est nobis legis spiritualis intelligentia que antea latebat” RatDivOff I, 3, 36.

I46 Por. „Et aperta est celestis regni ianua et data est nobis fortitudo ut uinci, nisi uelimus, a carnali concupisecentia nequeamus" - RatDivOff I, 3, 36 .

${ }^{147}$ Por. ,[...] eleuatur in uespera cuiuslibet sabbati Quadragesime, quando officium diei dominice inchoatur ut clerus possit in sanctuarium intueri, quia dominicam recolit resurectionem" - RatDivOff I, 3, 36.

${ }^{\mathrm{I} 48}$ Por. ,[...] qui per eos crediderunt seu credunt et credent; fideles autem ad uitam predestinati sunt lapides in structura huius muri qui semper usque in finem huius mundi edificabitur" - RatDivOff I, I, 9.
} 
w budowę świątyni, niezależnie od stanu czy zamożności. Wznoszenie świątyni to szczególne działanie, które wyraża jedność, wzajemną troskę, a nade wszystko miłość, ponieważ prawdziwa miłość niesie ,największe staranie wobec wdów, starych, sierot i słabych, i z tego powodu, aby otrzymali dobrodziejstwo, starają się pracować rękami"'49. Wszyscy angażują się w budowę tego dzieła, jakim jest ziemska świątynia, gdyż stanowi ona wyraz naszego zaangażowania i troski o budowę niebieskiego Jeruzalem - ,ludzie do budowy niebieskiego Jeruzalem nie mogą razem łączyć się bez miłości, którą Duch Święty pobudza"'50.

Kamienie wykorzystywane do budowy świątyni są czworokątne i płaskie, co ma wyrażać świętość, czystość i solidność. To poszczególni wierni rozmieszczani rękami Najwyższego Artysty w tej Bożej budowli, jaką jest Kościół ${ }^{15}$. Społecznie ważną rolę odgrywają też ci, którzy przekazują Ewangelię, a na świadectwie których opiera się wiara innych. Są to osoby, które pobudzają wiarę braci swoją pracą dla królestwa niebieskiego. Stanowią oni kamienie, na które nakłada się inny ,kamień dla dźwigania (go) jako budowli" ${ }^{52}$. Solidność i trwałość całej świątyni zapewniają wyjątkowi mężowie, którzy dają świadectwo swej doskonałości poprzez dobroczynność i modlitwę. To świadectwo jest na tyle mocne, że potrafi utrzymać słabych w wierze i dać im oparcie. Oni właśnie „są prawdziwie największymi kamieniami, wygładzonymi, doskonałymi czworokątnymi, które są położone po obydwu stronach, z zewnątrz, w których środku leżą mniejsze kamienie, są doskonalsi mężowie, którzy przez swoje dobrodziejstwa i modlitwy zatrzymują słabszych w świętym Kościele"'53.

Wznoszenie gmachu świątyni nie jest pozbawione jednak od przeszkód i trudności. I na to Speculator znajduje uzasadnienie. Budowa świątyni to nieustanna walka z wrogami. Tego samego doświadczali Żydzi wznoszący świątynię jerozolimską, co Durand symbolicznie określił tak: „Jedną ręką nosili kamienie do muru, a drugą ręką walczyli przeciw wrogom”. Zawsze

${ }^{149}$ Por. „Vera caritas sollicitudinem maximam habet mixtam pro uiduis, senibus, pupillis et debilibus; et ideo student operari manibus ut habeant unde beneficiant" - RatDivOff I, I, IO.

${ }^{\text {I50 }}$ „Homines ad edificium celestis Ierusalem possunt simul sine caritate iungi quam Spiritus sanctus operatur" - RatDivOff I, I, IO.

${ }^{151}$ Por. RatDivOff I, I, IO.

${ }_{152}$ Por. „Habet lapidem super se ad ferendum pro edificio quicumque laborem fraternum portat" - RatDivOff I, I, 9.

${ }^{153}$ „Grossiores uero lapides et politi seu quadrati, qui ponuntur altrinsecus foris in quorum medio minores lapides iacent, sunt uiri perfectiores qui suis meritis et orationibus continent infirmiores in sancta Ecclesia" - RatDivOff I, I, 9. 
pojawia się ktoś, kto usiłuje powstrzymać nasze czyny. To w dalszym ciągu obraz Kościoła walczącego, wspieranego z wysoka przez Pana, uzbrajanego w tarczę wiary, zbroję sprawiedliwości, hełm zbawienia i miecz słowa Bożego (por. Ef 6, I4-I7). Te narzędzia stanowią jedyną obronę w walce z wszelkimi przeciwnościami i zasadzkami Szatana. Kościół jest wspomagany przez pasterzy, którzy w miejsce Chrystusa uczą wiernych rozumienia Pisma Świętego oraz umacniania wiary poprzez modlitwę $e^{154}$.

Wizja Kościoła u Duranda jest osadzona mocno w Eucharystii. Każdy z ołtarzy znajdujących się niegdyś w świątyni jerozolimskiej obrazuje pewien aspekt Kościoła. Rozróżnienie na ołtarz wyższy i niższy skutkuje tym, że wyższy przedstawia Kościół triumfujący, natomiast niższy to Kościół walczący. Kościół walczący to Kościół, który jeszcze buduje ołtarze z kamieni nieociosanych, a Kościół triumfujący jest tym, który już uczestniczy w radości Pana, co mają symbolizować słowa Ps 5I (50), 2I: „będą składać cielce na Twoim ołtarzu"'55.

Dalsze rozróżnienie na ołtarz wewnętrzny i zewnętrzny odwołuje się do sakramentologii. Kiedy bowiem ołtarz wewnętrzny jest sercem, i to zarówno sercem naszym, jak i sercem świata, wiarą we wcielenie i pamiątką ofiary krzyża, to „ołtarz zewnętrzny jest jeszcze obrazem sakramentów Kościoła”" Ołtarz nie przestaje jednak też być pamiątką stołu, przy którym Chrystus ucztował ze swoimi uczniami, ustanawiając Nowe Przymierze ${ }^{\mathrm{I} 7}$.

\section{b) Członkowie Kościoła}

\section{Apostołowie, biskupi i doktorzy Kościoła}

Durand dość często przypisuje apostołom rolę podobną do roli Chrystusa. I tak, wraz z prorokami, zgodnie z Ef 2, 20, apostołowie stanowią fundament świątyni, której kamieniem węgielnym jest Chrystus ${ }^{158}$. Skoro Chrystus jest bramą ${ }^{159}$,

\footnotetext{
${ }_{154}$ Por. RatDivOff I, I, II.

155 Por. „Est et altare superius Ecclesia triumphans, de quo dicitur: «Tunc impones super altare tuum vitulos». Altare autem inferius est Ecclesia militans, de quo legitur: «Si altare lapideum feceris michi, non edificabis illud de sectis lapidibus»" - RatDivOff I, 2, 3 .

${ }^{156}$ „Altare etiam exterius sunt ecclesiastica sacramenta” - RatDivOff I, 2, 3.

157 Por. „[Altare] significat mensam in qua cum discipulis conuiuatus est Christus" RatDivOff I, 2, 3.

${ }_{158}$ Por. RatDivOff I, I, 9.

${ }^{159}$ Por. „Ostium ecclesie Christus est” - RatDivOff I, I, 26.
} 
to apostołowie są drzwiami, które odpierają ataki wrogów przebywających na zewnątrz ${ }^{160}$. Skoro ołtarz symbolizuje Chrystusa, to stopnie, które do Niego prowadzą, muszą mieć podobne odniesienie, jak kamień węgielny i fundament, zatem „stopnie, po których wstępuje się do ołtarza, ukazują w sposób duchowy apostołów i męczenników Chrystusa, którzy z miłości do Niego przelali swoją krew"'16. To bardzo ważna interpretacja, która niejako potwierdza związek ołtarza z relikwiami świętych umieszczanymi pod nim ${ }^{162}$. Przykład świętych pobudza ludzi każdej epoki i w sposób jasny wskazuje na Chrystusa jako cel życia i jego najwyższą wartość ${ }^{163}$. Nawiązaniem do apostołów i męczenników są również puszki umieszczane na ołtarzu, którym jest Chrystus ${ }^{164}$. Natomiast utensylia uposażające kielich, takie jak palki, oraz szaty nazywane popularnie bielizną kielichową (korporały i puryfikaterze) są przyrównywane do świętych wyznawców i dziewic, czy po prostu do wszystkich innych ${ }^{165}$. Durand przytacza tutaj słowa proroka Izajasza: „Tych podobnie szatą ustroisz”'166 - bliskość i przynależność do Chrystusa jest najcenniejszą szatą, w jaką tylko można być przyodzianym.

I60 Por. „Apostoli etiam porte eius sunt, dictum est autem ostium ab obsistendo hiis qui foris sunt, uel ab ostendendo aditum" - RatDivOff I, I, 26.

I6I „Gradus quibus ad altare ascenditur spiritualiter demonstrant apostolos et martyres Christi quos, quia pro eius amore sanguinem suum fuderunt" - RatDivOff I, 2, I3.

${ }_{162}$ Zwyczaj budowania ołtarzy na grobach męczenników jest znany od starożytności, od samego początku chrześcijańskiego budownictwa sakralnego. Pisał o tym św. Ambroży: „Dla uczczenia ciał męczenników oraz innych świętych, jak i dla zaznaczenia prawdy, że ofiara członków wywodzi swój początek z ofiary Głowy, wypada nad ich grobami wznosić ołtarze albo składać relikwie pod ołtarzami tak, by zwycięskie ofiary znalazły się w tym miejscu, gdzie Chrystus jest ofiarą. Lecz On za wszystkich cierpiał, na ołtarzu, oni pod ołtarzem, gdyż Jego męką zostali odkupieni" - S. Ambrosius, Epistula 22, I3 (PL I6, I023); Ps. Maximus Taurinensis, Sermo, 78 (PL 57, 689-690), za: Obrzędy poświęcenia kościoła i ołtarza IV, 5, Katowice 2009, s. II8.

163 Dziś ten związek jest widoczny w prefacji mszalnej o świętych (nr 7I): „Przez wspaniałe świadectwo życia Twoich Świętych obdarzasz swój Kościół nową mocą i dajesz nam dowody swojej miłości. Przykład Świętych nas pobudza, a ich bratnia modlitwa nas wspomaga, abyśmy osiągnęli pełnię zbawienia" (Mszat rzymski dla diecezji polskich, wyd. drugie, poszerzone, Poznań 20I0, s. 88*) oraz o świętych męczennikach ( $\mathrm{nr} 72$ ): „Ty w męczeństwie świętego N. ukazałeś cuda swojej łaski, on bowiem naśladując Chrystusa, przelał krew ku Twojej chwale" (Mszat rzymski dla diecezji polskich, dz. cyt., s. 89*).

${ }^{164}$ Por. „Capse autem, super altare quod est Christus posite, sunt apostoli et martyres” RatDivOff I, 3, 25.

165 Por. „Palle uero et uestes sunt confessores et uirgines uel omnes sancti”- RatDivOff I, 3, 25.

166 Por. „[Sancti] de quibus Propheta ait ad Dominum: «Hiis sicut uestimento uestieris»” RatDivOff I, 3, 25. 
W dalszym rozważaniu funkcja i status apostołów, a także ewangelistów odzwierciedla się w funkcjach biskupów, nauczycieli i doktorów Kościoła. Zostaje w ten sposób wyrażona sukcesja apostolska i kontynuacja misji apostołów poprzez posługę biskupów, którzy są ich następcami. Źródło takiego znaczenia, na którym opiera się tutaj biskup Mende, znajduje się w Liście do Galatów, gdzie św. Paweł określa Jakuba, Kefasa i Jana mianem filarów Kościoła (por. Ga 2, 9). Widać to szczególnie w miejscu, w którym Durand pisze, że apostołowie są , podstawami kolumn, ponieważ podtrzymują biskupów i całą konstrukcję Kościoła”'167; „, ,biskupi i doktorzy Kościoła stanowią kolumny, na których nauce wspiera się świątynia Boża"168. Jest tu też pewna analogia pomiędzy biskupami a ewangelistami, mianowicie jak biskupi i doktorzy duchowo wspierają świątynię Boga, tak ewangeliści „wspierają tron Boga”, oni też z powodu brzemienia nauczania nazywani są srebrnymi kolumnami ${ }^{169}$. Wszystkie te opisy ukazują niezwykłe zadanie, ale i odpowiedzialność, jaka spoczywa na biskupach i doktorach, gdyż to właśnie oni stanowią całą strukturę nośną dla Kościoła Bożego. Biskupi i nauczyciele są także „głowicami tych kolumn, ponieważ ich orzeczeniami kierują się wierni" ${ }^{770}$, a tym samym stanowią aktualną wykładnię prawd wiary. W głowicach tych kolumn Speculator dostrzega także słowa Pisma Świętego, które jest poddawane wiernym do rozważania ${ }^{171}$. Nauczanie doktorów Kościoła zostało również przyrównane do kamieni tworzących ściany kościoła, ponieważ biorą oni odpowiedzialność za kształtowanie młodych, upominanie oraz umacnianie w Kościele ${ }^{172}$. Kształtowanie innych wiąże się też z oświecaniem, dlatego apostołowie wraz z doktorami Kościoła porównywani są do lamp: „Kościół jaśnieje ich nauką"173.

${ }^{167}$ Por. „Bases columpnarum sunt apostolici, episcopos et uniuersalem Ecclesie machinam supportantes" - RatDivOff I, I, 27.

${ }^{168}$ „Columpne ecclesie episcopi et doctores sunt, qui templum Dei per doctrinam” RatDivOff I, I, 27.

${ }^{169}$, ,... [ sicut et euangeliste tronum Dei, spiritualiter sustinent. Hii nempe pro sonoritate diuini eloquii argentee columpne dicuntur" - RatDivOff I, I, 27.

170 „Capita columpnarum sunt mentes episcoporum et doctorum, sicut enim capite membra, sic mente nostra uerba diriguntur et opera" - RatDivOff I, I, 27.

${ }^{171}$ Por. „Capitella quoque sunt uerba sacre Scripture quorum meditationi subdimur et obseruantie" - RatDivOff I, I, 27.

${ }_{172}$ Por. „Lapis uero super lapidem ponitur quando magistri Ecclesie iuniores in proprium studium assumunt ad docendum et ad corregendum et stabiliendum in sancta Ecclesia" RatDivOff I, I, 9.

${ }^{173}$ Por. ,[...] luminaria ecclesie significant apostolos et ceteros doctores quorum doctrina fulget Ecclesia" - RatDivOff I, I, 40. 
Bliska temu porównaniu jest także alegoria okien. „Przez okratowania, które jednakowoż są przed oknami, rozumiemy proroków lub innych mało znanych doktorów Kościoła walczącego, w których, z powodu dwóch zasad miłości niekiedy dwie kolumny są podwajane, zgodnie z tym, że i apostołowie po dwóch są posłani do przepowiadania" (por. Łk IO, I) ${ }^{174}$. W roli depozytu wiary występuje teraz Kościół reprezentowany przez widzialną budowlę, w obronie którego stają prorocy i doktorzy. Misja głoszenia słowa Bożego i jego obrony staje się zatem szczególnym zadaniem osób, które zostały namaszczone do jego przepowiadania.

Nauczycieli symbolizują także płytkie miski o równej szerokości, służące do rozgrzania, ponieważ nie chowają skarbu serca, lecz starają się z niego wydobywać zarówno to ,co nowe, jak i to, co stare. Nie kładą również lampy oliwnej pod korcem, lecz na świeczniku, tzn. na widoku wszystkich (por. Mt 5, I5), żeby ci którzy są w domu, uzyskali światło i jasność Ducha Świętego.

\section{Kaznodzieje}

Wiele elementów architektonicznych jest odwołaniem do alegorii związanej z osobą kaznodziei. Przedstawia go chociażby wieża kościelna, przywołująca takie jego funkcje jak umacnianie i obrona Kościoła ${ }^{175}$. Sam wierzchołek wieży, jej zwieńczenie, przedstawia życie lub duszę przełożonego, który kieruje się ku wyżynom. O osobie kaznodziei przypomina także kogut umieszczony na kościele. „Kogut bowiem - strażnik głębokiej nocy - rozdziela swoim śpiewem godziny, budzi śpiących, gdy zbliża się dzień rozpoczyna śpiew, lecz wcześniej on sam wybudza się do śpiewu trzepotem skrzydeł"176. Durand ukazuje w ten sposób, że noc symbolizuje czas ciemności i grzechu, stan doczesności, a zadaniem kaznodziei, jest wybudzanie z tego stanu w sposób analogiczny do wybudzania podejmowanego przez koguta, gdy nastaje dzień.

${ }^{174}$ Por. „Per cancellos uero qui sunt ante fenestras, prophetas uel alios doctores obscuros intelligimus Ecclesie militantis in quibus ob duo caritatis precepta quandoque due columne duplicantur, secundum quod et apostoli bini ad predicandum mittuntur" - RatDivOff I, I, 25.

${ }^{175}$ Por. „Turres ecclesie predicatores sunt et prelati Ecclesie qui sunt munimen et defensio eius [...] Pinnaculum turris uitam mentem prelati que ad alta tendit representat" - RatDivOff I, I, 2I.

${ }^{176}$ „Gallus supra ecclesiam positus predicatores designat, gallus enim profunde noctis peruigil horas suo cantu diuidit, dormientes excitat, diem appropinquantem precinit, sed prius seipsum alarum uerbere ad cantandum exicitat" - RatDivOff I, I, 22. 
Kaznodzieja ma być zwiastunem światła, które nadejdzie w dzień sądu, ma pouczać i wybudzać z grzechu, wzywać do pokuty. Pręt, na którym umieszczony jest kogut, przedstawia mowę kaznodziejską, która nie pochodzi od człowieka, ale od samego Boga. Jako że kogut jest umieszczany ponad krzyżem, interpretacja zostaje dodatkowo wzmocniona, ponieważ ukazuje, że za naukami kaznodziei stoi doskonałość Pisma Świętego i Misterium Chrystusa, gdyż nad konającym Chrystusem umieszczono napis, który stał się niezatartym wobec wołania Chrystusa z krzyża: „Wykonało się!” (J I9, 30 $)^{177}$. Kaznodzieja ma być też obrońcą jedności Kościoła ${ }^{178}$.

Kaznodzieje pełnią niejako funkcję nośną w odniesieniu do całej budowli, są bowiem ukazani jako belki czy jako sklepienie. Sklepienia zdobią kościół, bywają często podziwiane, ale też wzmacniają go. Analogicznie kaznodzieje, ponieważ ich posługa jest widoczna, powinni stanowić dla wiernych przy$\mathrm{kład}^{179}$. Durand nie pozostawia jednak żadnej wątpliwości co do Osoby, która wznosi świątynię i co do materiału, jaki został użyty - „Bóg bowiem wzniósł sobie Kościół z żywych kamieni i z drewna niepodlegającego zniszczeniu"ı80.

Nie tylko formy przestrzenne i nośne świątyni są przedstawiane na podobieństwo kaznodziei. Przyjrzyjmy się jeszcze drobnym elementom, które również zostają porównane $\mathrm{z}$ heroldami słowa. I tak zwyczajne szczypce do świec, „których podwójnym ostrzem jest ujarzmiany płomień, są przepowiadającymi [kaznodziejami], którzy nas pouczają harmonijnie zestawionymi stronicami obu testamentów i kształtując poprzez obyczaje zapalają [nas] do miłości”'18I. Kaznodzieja ma pouczać lud poprzez głoszone słowo Boże. Durand już w XIII wieku apeluje, aby to głoszenie opierało się na egzegezie świętego tekstu, na zestawianiu stronnic obu Testamentów, tak Starego, jak i Nowego i thumaczeniu go wiernym. Nauczanie to ma się opierać na Biblii.

${ }^{177}$ Por. „Quod uero uirga ipsa est supra crucem seu summitatem ecclesie posita innuit sermonem Scripturarum consummatum esse et confirmatum, unde Dominus in passione ait: Consummatum est, et titulus eius super eum indelebiliter scriptus est" - RatDivOff I, I, 22.

${ }_{178}$ Por. ,[...] predicatores qui Ecclesie muniunt unitatem” - RatDivOff I, I, 29.

179 Por. „Tigna in ecclesia sunt predicatores qui eam spiritualiter subleuant. Laquearia etiam siue celature sunt predicatores qui illam orant uel roborant, de quibus, quia per uitia non putrescunt" - RatDivOff I, I, 3 I.

${ }^{180}$ „Deus enim Ecclesiam sibi construit uiuis ex lapidibus et lignis imputribilibus” RatDivOff I, I, 3I.

${ }^{181}$ „Rursus forcipies, quorum gemino dente componitur ignis, sunt predicatores qui nos consonis utriusque testament paginis instruunt, et moribus componentes ad caritatem accendunt" - RatDivOff I, 3, 29. 
W takiej metodzie biskup Mende widzi możliwość rozpalenia serc ludu Bożego do wzrastania w miłości.

\section{Pustelnicy}

W swojej interpretacji Durand nawiązuje ponadto do tak niepozornej grupy, jaką stanowią pustelnicy. Wykazując podstawowe cechy ich egzystencji, mianowicie życie w samotności, będące życiem ukrytym, którego stają się czcicielami, porównuje ich do krypt bądź też grot podziemnych, które są ukryte i schowane pod widoczną powierzchnią świątyni ${ }^{182}$.

\section{Fundatorzy}

Także fundatorzy i władcy przychylni Kościołowi musieli znaleźć swoje odniesienie. Durand przedstawia ich jako belki nośne, które łączą i zespajają budowlę kościelną, symbolizującą wówczas Kościół jako wspólnotę. Są tymi, którzy Kościoła bronią i zapewniają mu jedność w sposób czynny, ale nieco inaczej niż kaznodzieje ${ }^{183}$.

\section{WNIOSKI}

Dla Duranda, przedstawiciela średniowiecza, każdy szczegół i element, czy to materialny, strukturalny, czy funkcjonalny budynku kościoła i rytuału liturgicznego jest nośnikiem znaczenia symbolicznego. Tym, co może jednak zastanawiać współczesnego czytelnika, jest fakt, że Durand pomija całkowicie opis wartości artystycznych budynku świątyni gotyckiej i zrozumienia ich ewentualnego związku z treściami religijnymi ${ }^{\mathrm{i} 4}$. Świadczy to o tym, że w średniowieczu świątynia stanowiła przestrzeń opisywaną nade wszystko

\footnotetext{
${ }^{182}$ Por. „Cripte siue specus subterranee, que in quibusdam fiunt ecclesiis, sunt heremite, cultores siquidem secretioris uite" - RatDivOff I, I, I9.

${ }_{183}$ Por. „Trabes que domum coniungunt sunt principes seculi uel predicatores qui Ecclesie muniunt unitatem, hii uerbo, illi facto" - RatDivOff I, I, 29.

${ }^{184}$ Por. Myśliciele, kronikarze i artyści o sztuce. Od starożytności do I50o roku, wyb. i oprac. J. Białostocki, Gdańsk 200I, s. I79.
} 
symbolicznie, a nie artystycznie. Odnalezienie się w liturgicznej przestrzeni celebracji było postawione ponad doświadczenie estetyczne.

Średniowieczna alegoria szukała interpretacji niemalże do przesady, zyskując sobie tym samym wielu przeciwników. Paradoksem jednak może się wydawać fakt, że styl gotycki rozwijający się równolegle do tej metody, mimo silnego przeakcentowania treści, w żaden sposób nie utracił na swym pięknie architektonicznym. Czyżby w znaczeniu symbolicznym krył się klucz do polepszenia jakości sztuki sakralnej?

Dzieło Duranda jest uważane za sumę średniowiecznej wykładni alegorycznej dotyczącej Ordo Missae. W końcu sam inicjator Ruchu Liturgicznego - Prosper Guéranger stwierdził, że czwarta księga Rationale divinorum officiorum była „ostatnim słowem średniowiecza na temat misterium kultu” ${ }^{185}$, a Anselm Davril orzekł, że: „Rationale stało się dla nauki o liturgii średniowiecznej tym, czym były Sentencje Piotra Lombarda dla teologii’'186.

\section{Bibliografia}

Duranti G., Rationale divinorum officiorum, direct. S. della Torre, M. Marinelli, Città del Vaticano 200I (Monumenta Studia Instrumenta Liturgica, II).

Durandus W., Neale J. M., Webb B., The symbolism of Churches and Churches Ornaments a translationof the first book of the "Rationale Divinorum Officiorum" written by William Durandus sometime bishop of Mende with an Introductory essay and notes, London 1906.

Gvillelmi Dvranti Rationale divinorvm officiorvm I-IV, edid. A. Davril, T. M. Thibodeau, Tvrnholti 1995 (Corpvs Christianorvm. Continuatio Mediaeualis, I40).

Katechizm Kościoła Katolickiego, wyd. 2. popr., Poznań 2002.

Koch W., Style w architekturze. Arcydzieła budownictwa europejskiego od antyku po czasy współczesne, przekł. W. Baraniewski i in., koordynator przekł. L. Krzyżanowski, Warszawa 1996.

Komentarz praktyczny do Nowego Testamentu, t. 2, red. A. Jankowski, K. Romaniuk, L. Stachowiak, Poznań-Kraków 1999.

${ }^{185}$ Durand z Mende, w: Leksykon liturgii, dz. cyt., s. 349.

${ }^{186}$ A. Davril, Préambule, dz. cyt., s. VIII. 
Kunzler M., Liturgia Kościoła, przeł. L. Balter, Poznań 1999 (Amateca. Podręczniki Teologii Katolickiej, Io).

Leksykon liturgii, oprac. B. Nadolski, Poznań 2006.

Mieczkowski J., Superson J., Teologiczne usytuowanie ottarza $w$ światyni chrześcijańskiej, „Collectanea Theologica” 78 (2008) nr I, s. IIO-I29.

Obrzędy poświęcenia kościoła i ottarza IV, 5, Katowice 2009.

Ogólne wprowadzenie do Mszału rzymskiego, Poznań 2004.

Ostrowski M., Nabożeństwo w drodze, s. 4, http://www.pastoralna.pl/files/308 \%20Nabozenstwo\%20w\%20drodze.pdf (6.07.2018).

Romaniuk K., O siedmiu darach Ducha Świętego, Warszawa 1992.

\section{SUMMARY}

\section{The allegorical interpretation of the temple in the first book of Rationale divinorum officiorum by G. Duranti}

The article presentes an attempt to group single elements whose interpretation was undertaken by Guillelmi Duranti (comparanda) in the comparison he most frequently used (comparantis), in other words, to which elements are compared. The classification of particular collections of comparatives (comparantis) for the purposes of work has been specified and created by the author. The work of G. Duranti was a result of concern about priests and faithful of his diocese, for whom he wanted to create a textbook that explained questions raised in the liturgy. The three chapters of the first book written by G. Duranti show that the liturgical space is not lifeless, that each element has a meaning and can help man to explore the reality, where they are and what they participate in. 